\title{
Corporate Governance And Firm Performance
}

\author{
Sanjai Bhagat
}

Brian Bolton

\section{April 2007}

We thank Lucian Bebchuk, Paul Gompers and seminar participants at Cornell University, Dartmouth College (Tuck), University of Chicago, University of Rochester, and Yale University (Corporate Law Seminar) for helpful comments on a previous draft of this paper.

Please address correspondence to Sanjai Bhagat, Leeds School of Business, University of Colorado, Boulder, CO 80309-0419.sanjai.bhagat@colorado.edu 


\title{
Corporate Governance And Firm Performance
}

\begin{abstract}
How is corporate governance measured? What is the relationship between corporate governance and performance? This paper sheds light on these questions while taking into account the endogeneity of the relationships among corporate governance, corporate performance, corporate capital structure, and corporate ownership structure. We make three additional contributions to the literature:

First, we find that better governance as measured by the Gompers, Ishii, and Metrick (GIM, 2003) and Bebchuk, Cohen and Ferrell (BCF, 2004) indices, stock ownership of board members, and CEO-Chair separation is significantly positively correlated with better contemporaneous and subsequent operating performance.

Second, contrary to claims in GIM and BCF, none of the governance measures are correlated with future stock market performance. In several instances inferences regarding the (stock market) performance and governance relationship do depend on whether or not one takes into account the endogenous nature of the relationship between governance and (stock market) performance.
\end{abstract}

Third, given poor firm performance, the probability of disciplinary management turnover is positively correlated with stock ownership of board members, and board independence. However, better governed firms as measured by the GIM and BCF indices are less likely to experience disciplinary management turnover in spite of their poor performance.

The above results highlight the strategic importance of board incentives. Our recommendations on board incentives are consistent with the implications of Hermalin and Weisbach (2007). 


\section{Introduction}

In an important and oft-cited paper, Gompers, Ishii, and Metrick (GIM, 2003) study the impact of corporate governance on firm performance during the 1990s. They find that stock returns of firms with strong shareholder rights outperform, on a risk-adjusted basis, returns of firms with weak shareholder rights by 8.5 percent per year during this decade. Given this result, serious concerns can be raised about the efficient market hypothesis, since these portfolios could be constructed with publicly available data. On the policy domain, corporate governance proponents have prominently cited this result as evidence that good governance (as measured by GIM) has a positive impact on corporate performance.

There are three alternative ways of interpreting the superior return performance of companies with strong shareholder rights. First, these results could be sample-period specific; hence companies with strong shareholder rights during the current decade of 2000s may not have exhibited superior return performance. In fact, in a very recent paper, Core, Guay and Rusticus (2005) carefully document that in the current decade share returns of companies with strong shareholder rights do not outperform those with weak shareholder rights. Second, the riskadjustment might not have been done properly; in other words, the governance factor might be correlated with some unobservable risk factor(s). Third, the relation between corporate governance and performance might be endogenous raising doubts about the causality explanation. There is a significant body of theoretical and empirical literature in accounting and finance that considers the relations among corporate governance, management turnover, corporate performance, corporate capital structure, and corporate ownership structure. Hence, from an econometric viewpoint, to study the relationship between any two of these variables one would need to formulate a system of simultaneous equations that specifies the relationships among these variables.

What if after accounting for sample period specificity, risk-adjustment, and endogeneity, the data indicates that share returns of companies with strong shareholder rights are similar to 
those with weak shareholder rights? What might we infer about the impact of corporate governance on performance from this result? It is still possible that governance might have a positive impact on performance, but that good governance, as measured by GIM, might not be the appropriate corporate governance metric.

An impressive set of recent papers have considered alternative measures of corporate governance, and studied the impact of these governance measures on firm performance. GIM's governance measure is an equally-weighted index of 24 corporate governance provisions compiled by the Investor Responsibility Research Center (IRRC), such as, poison pills, golden parachutes, classified boards, cumulative voting, and supermajority rules to approve mergers. Bebchuk, Cohen and Ferrell (BCF, 2004) recognize that some of these 24 provisions might matter more than others and that some of these provisions may be correlated. Accordingly, they create an "entrenchment index" comprising of six provisions - four provisions that limit shareholder rights and two that make potential hostile takeovers more difficult. While the above noted studies use IRRC data, Brown and Caylor (2004) use Institutional Shareholder Services (ISS) data to create their governance index. This index considers 52 corporate governance features such as board structure and processes, corporate charter issues such as poison pills, management and director compensation and stock ownership.

There is a related strand of the literature that considers corporate board characteristics as important determinants of corporate governance: board independence (see Hermalin and Weisbach $(1998,2003)$ ), stock ownership of board members (see Bhagat, Carey, and Elson (1999)), and whether the Chairman and CEO positions are occupied by the same or two different individuals (see Brickley, Coles, and Jarrell (1997)). Can a single board characteristic be as effective a measure of corporate governance as indices that consider 52 (as in Brown and Caylor), 24 (as in GIM) or other multiple measures of corporate charter provisions, and board characteristics? While, ultimately, this is an empirical question, on both economic and econometric grounds it is possible for a single board characteristic to be as effective a measure of 
corporate governance. Corporate boards have the power to make, or at least, ratify all important decisions including decisions about investment policy, management compensation policy, and board governance itself. It is plausible that board members with appropriate stock ownership will have the incentive to provide effective monitoring and oversight of important corporate decisions noted above; hence board independence or ownership can be a good proxy for overall good governance. Furthermore, the measurement error in measuring board ownership can be less than the total measurement error in measuring a multitude of board processes, compensation structure, and charter provisions. Finally, while board characteristics, corporate charter provisions, and management compensation features do characterize a company's governance, construction of a governance index requires that the above variables be weighted. The weights a particular index assigns to individual board characteristics, charter provisions, etc. is important. If the weights are not consistent with the weights used by informed market participants in assessing the relation between governance and firm performance, then incorrect inferences would be made regarding the relation between governance and firm performance.

Our primary contribution to the literature is a comprehensive and econometrically defensible analysis of the relation between corporate governance and performance. We take into account the endogenous nature of the relation between governance and performance. Also, with the help of a simultaneous equations framework we take into account the relations among corporate governance, performance, capital structure, and ownership structure. We make four additional contributions to the literature:

First, instead of considering just a single measure of governance (as prior studies in the literature have done), we consider seven different governance measures. We find that better governance as measured by the GIM and BCF indices, stock ownership of board members, and CEO-Chair separation is significantly positively correlated with better contemporaneous and subsequent operating performance. Additionally, better governance as measured by Brown and Caylor, and The Corporate Library is not significantly correlated with better contemporaneous or 
subsequent operating performance. ${ }^{1}$ Also, interestingly, board independence is negatively correlated with contemporaneous and subsequent operating performance. This is especially relevant in light of the prominence that board independence has received in the recent NYSE and NASDAQ corporate governance listing requirements. ${ }^{2}$ We conduct a battery of robustness checks including (a) consideration of alternate instruments for estimating the system of equations, (b) consideration of diagnostic tests to ensure that our instruments are valid and our system of equations is well-identified, and (c) alternative estimates of the standard errors of our model's estimated coefficients. These robustness checks provide consistent results and increase our confidence in the performance-governance relation as noted above.

Second, contrary to claims in GIM and BCF, none of the governance measures are correlated with future stock market performance. In several instances inferences regarding the (stock market) performance and governance relationship do depend on whether or not one takes into account the endogenous nature of the relationship between governance and (stock market) performance. ${ }^{3}$ For example, the OLS estimate indicates a significantly negative relation between the GIM index and next year's Tobin's Q. However, after taking into account the endogenous nature of the relation between governance and performance, we find a positive but statistically insignificant relation between the GIM index and next year's Tobin's Q.

Third, given poor firm performance, the probability of disciplinary management turnover is positively correlated with stock ownership of board members, and with board independence. However, given poor firm performance, the probability of disciplinary management turnover is negatively correlated with better governance measures as proposed by GIM and BCF. In other

\footnotetext{
${ }^{1}$ The Corporate Library (TCL) is a commercial vendor that uses a proprietary weighting scheme to include over a hundred variables concerning board characteristics, management compensation policy, and antitakeover measures in constructing a corporate governance index.

${ }^{2}$ See SEC ruling "NASD and NYSE Rulemaking Relating to Corporate Governance," in http://www.sec.gov/rules/sro/34-48745.htm, and http://www.sec.gov/rules/sro/nyse/34-50625.pdf.

${ }^{3}$ The BCF index has become popular with industry experts giving advice to institutional investors on investments and proxy voting; for example, see Hermes Pensions Management (2005), and www.glasslewis.com.
} 
words, so called "better governed firms" as measured by the GIM and BCF indices are less likely to experience disciplinary management turnover in spite of their poor performance.

Fourth, we contribute to the growing literature on the relation between corporate governance, and accounting and finance variables. Ashbaugh-Skaife, Collins, and Lafond (2006) investigate the relation between corporate governance and credit ratings. They consider the GIM index and various board characteristics including board independence and compensation as separate governance measures. Cremers and Nair (2005) focus on the interaction between several governance measures and firm performance. They consider the GIM index as a measure of external governance and pension fund block ownership as a measure of inside governance; they also investigate other similar governance measures. Defond, Hann and Hu (2005) consider the cross-sectional relation between the market's response to the appointment of an accounting expert on the board and its corporate governance; they construct a governance index that gives equal weight to six variables including board independence, the GIM index, and audit committee structure. Bowen, Rajgopal, and Venkatachalam (2005) analyze the relation between corporate governance, accounting discretion and firm performance; they consider several board characteristics and the GIM index as separate measures of governance. ${ }^{4}$ Even this brief review of the literature on the relation between governance, and accounting and finance variables suggests lack of an agreed upon measure of governance. This study proposes a governance measure, namely, dollar ownership of the board members - this measure is simple, intuitive, less prone to measurement error, and not subject to the problem of weighting a multitude of governance provisions in constructing a governance index. Consideration of this governance measure by future researchers would enhance the comparability of research findings.

\footnotetext{
${ }^{4}$ Given space constraints we are unable to review the vast and growing literature on the relation between governance and finance, accounting, and corporate law variables; our apologies to the authors we have not cited here. In addition to the papers noted above, we refer the reader to Erickson, Hanlon, and Maydew (2006), Anderson, Mansi and Reeb (2004), Marquardt and Wiedman (2005), Rajan and Wulf (2006), Bergstresser and Philippon (2006), Gillan (2006), Yermack (2006), Bushman, Chen, Engel and Smith (2004), and Bebchuk and Cohen (2005).
} 
The above findings have important implications for researchers, senior policy makers, and corporate boards: Efforts to improve corporate governance should focus on stock ownership of board members - since it is positively related to both future operating performance, and to the probability of disciplinary management turnover in poorly performing firms. Proponents of board independence should note with caution the negative relation between board independence and future operating performance. Hence, if the purpose of board independence is to improve performance, then such efforts might be misguided. However, if the purpose of board independence is to discipline management of poorly performing firms, then board independence has merit. Finally, even though the GIM and BCF good governance indices are positively related to future operating performance, policy makers and corporate boards should be cautious in their emphasis on the components of these indices since this might exacerbate the problem of entrenched management, especially in those situations where management should be disciplined, that is, in poorly performing firms. ${ }^{5}$ Finally, our recommendations on incentive effects of board stock ownership are consistent with the implications of Hermalin and Weisbach (2007) who analyze the role of disclosure on the contractual and monitoring relationship between the board and the CEO. Hermalin and Weisbach highlight the costs and benefits of greater disclosure. Greater stock ownership by the board would help internalize these costs and benefits at the decision-making (board) level.

The remainder of the paper is organized as follows. The next section briefly reviews the literature on the relationship among corporate ownership structure, governance, performance and capital structure. Section III notes the sample and data, and discusses the estimation procedure. Section IV presents the results on the relation between governance and performance. Section V

\footnotetext{
${ }^{5}$ There is considerable interest among senior policy makers and corporate boards in understanding the determinants of good corporate governance, for example, see New York Times, April 10, 2005, page 3.6, "Fundamentally;" Wall Street Journal, October 12, 2004, page B.8, “Career Journal;" Financial Times FT.com, September 21, 2003, page 1 "Virtue Rewarded."
} 
focuses on the impact of governance in disciplining management in poorly performing companies. The final section concludes with a summary.

\section{Corporate Ownership Structure, Corporate Governance, Firm Performance, and Capital Structure}

Some governance features may be motivated by incentive-based economic models of managerial behavior. Broadly speaking, these models fall into two categories. In agency models, a divergence in the interests of managers and shareholders causes managers to take actions that are costly to shareholders. Contracts cannot preclude this activity if shareholders are unable to observe managerial behavior directly, but ownership by the manager may be used to induce managers to act in a manner that is consistent with the interest of shareholders. Grossman and Hart (1983) describe this problem.

Adverse selection models are motivated by the hypothesis of differential ability that cannot be observed by shareholders. In this setting, ownership may be used to induce revelation of the manager's private information about cash flow or her ability to generate cash flow, which cannot be observed directly by shareholders. A general treatment is provided by Myerson (1987).

In the above scenarios, some features of corporate governance may be interpreted as a characteristic of the contract that governs relations between shareholders and managers.

Governance is affected by the same unobservable features of managerial behavior or ability that are linked to ownership and performance.

At least since Berle and Means (1932), economists have emphasized the costs of diffused share-ownership; that is, the impact of ownership structure on performance. However, Demsetz (1983) argues that since we observe many successful public companies with diffused shareownership, clearly there must be offsetting benefits, for example, better risk-bearing. ${ }^{6}$ Also, for

\footnotetext{
${ }^{6}$ Investors preference for liquidity would lead to smaller blockholdings given that larger blocks are less liquid in the secondary market. Also, as highlighted by Black (1990) and Roe (1994), the public policy bias in the U.S. towards protecting minority shareholder rights increases the costs of holding large blocks.
} 
reasons related to performance-based compensation and insider information, firm performance could be a determinant of ownership. For example, superior firm performance leads to an increase in the value of stock options owned by management which, if exercised, would increase their share ownership. Also, if there are serious divergences between insider and market expectations of future firm performance then insiders have an incentive to adjust their ownership in relation to the expected future performance. Himmelberg, Hubbard and Palia (1999) argue that the ownership structure of the firm may be endogenously determined by the firm's contracting environment which differs across firms in observable and unobservable ways. For example, if the scope for perquisite consumption is low in a firm then a low level of management ownership may be the optimal incentive contract.

In a seminal paper, Grossman and Hart (1983) considered the ex ante efficiency perspective to derive predictions about a firm's financing decisions in an agency setting. Novaes and Zingales (1999) show that the optimal choice of debt from the viewpoint of shareholders differs from the optimal choice of debt from the viewpoint of managers. ${ }^{7}$ While the above focuses on capital structure and managerial entrenchment, a different strand of the literature has focused on the relation between capital structure and ownership structure; for example, see Grossman and Hart (1986) and Hart and Moore (1990).

This brief review of the inter-relationships among corporate governance, management turnover, corporate performance, corporate capital structure, and corporate ownership structure suggests that, from an econometric viewpoint, to study the relationship between corporate governance and performance, one would need to formulate a system of simultaneous equations

\footnotetext{
${ }^{7}$ The conflict of interest between managers and shareholders over financing policy arises because of three reasons. First, shareholders are much better diversified than managers who besides having stock and stock options on the firm have their human capital tied to the firm (Fama (1980)). Second, as suggested by Jensen (1986), a larger level of debt pre-commits the manager to working harder to generate and pay off the firm's cash flows to outside investors. Third, Harris and Raviv (1988) and Stulz (1988) argue that managers may increase leverage beyond what might be implied by some "optimal capital structure" in order to increase the voting power of their equity stakes, and reduce the likelihood of a takeover and the resulting possible loss of job-tenure.
} 
that specifies the relationships among the abovementioned variables. We specify the following system of four simultaneous equations:

$$
\begin{aligned}
& \text { Performance }=f_{1}\left(\text { Ownership, Governance, Capital Structure, } Z_{1}, \varepsilon_{1}\right), \\
& \text { Governance }=f_{2}\left(\text { Performance, Ownership, Capital Structure, } Z_{2}, \varepsilon_{2}\right), \\
& \text { Ownership }=f_{3}\left(\text { Governance, Performance, Capital Structure, } Z_{3}, \varepsilon_{3}\right) \text {, } \\
& \text { Capital Structure }=f_{4}\left(\text { Governance, Performance, Ownership, } Z_{4}, \varepsilon_{4}\right) \text {, }
\end{aligned}
$$

where the $Z_{\mathrm{i}}$ are vectors of control variables and instruments influencing the dependent variables and the $\varepsilon_{\mathrm{i}}$ are the error terms associated with exogenous noise and the unobservable features of managerial behavior or ability that explain cross-sectional variation in performance, ownership, capital structure and governance. The estimation issues for the above equations are discussed in the next section.

\section{Data and Estimation Issues}

\section{A. Data}

In this section we discuss the data sources for board variables, performance, leverage and instrumental variables. All variables including governance measures are described in Table 1. Board Variables: We obtain data on board independence, board ownership, and CEO-Chair duality from IRRC and TCL. We also obtain board size, median director ownership, median director age and median director tenure from these sources. The stock ownership variable does not include options. We consider the dollar value of stock ownership of the median director as the measure of stock ownership of board members. Our focus on the median director's ownership, instead of the average ownership, is motivated by the political economy literature on the median voter; see Shleifer and Murphy (2004), and Milavonic (2004). Also, directors, as economic agents, are more likely to focus on the impact on the dollar value of their holdings in the company rather than on the percentage ownership. 
Performance Variables: We use Compustat and Center for Research in Security Prices (CRSP) data for our performance variables. We use the annual accounting data from Compustat for calculating return-on-assets (“ROA”) and Tobin's Q. Following Barber and Lyon (1996), we calculate ROA as operating income before depreciation divided by total assets. For robustness, we also consider operating income after depreciation divided by total assets. Similar to GIM, we calculate Tobin's Q as (total assets + market value of equity - book value of equity - deferred taxes) divided by total assets. We use the CRSP monthly stock file to calculate monthly and annual stock returns. We calculate industry performance measures by taking the four-digit SIC code average (excluding the sample firm) performance for the specific time period.

Leverage: Consistent with Bebchuk, Cohen and Ferrell (2004), Graham, Lang, and Shackleford (2004), and Khanna and Tice (2005) we compute leverage as (long term debt + current portion of long term debt) divided by total assets. For robustness, we also consider alternative definitions of leverage as suggested by Baker and Wurgler (2002).

Instrumental Variables: The choice of instrumental variables is critical to the consistent estimation of (1a), (1b), (1c), and (1d). ${ }^{8}$ Our choice of instrumental variables is motivated by the extant literature; additionally, all of our analyses involving instrumental variables include tests for weak instruments as suggested by Stock and Yogo (2004), and the Hausman (1978) test for endogeneity. Also, we perform the Hahn and Hausman (2002) weak instrument test, the HansenSargan overidentification test, the Cragg-Donald test for model identification, and the AndersonRubin test for the joint significance of the set of endogenous variables in our system of equations. Additionally, we consider alternate instruments than the ones noted below. This is discussed later in this section and in section IV.B.1 below. We identify the following variables as instruments for ownership, performance, governance, and capital structure.

\footnotetext{
${ }^{8}$ The choice of appropriate instruments while never easy, is especially challenging in the context of this study. Almost any instrument variable identified for a particular endogenous variable in equation (1) will plausibly (based on extant theory and/or empirical evidence) be related to at least another, and possibly more, endogenous variable(s) in (1). Ashbaugh-Skaife, Collins, and Lafond (2006) make a similar point.
} 
CEO Tenure-to-Age: A CEO that has had five years of tenure at age 65 is likely to be of different quality and have a different equity ownership than a CEO that has had five years of tenure at age 50. These CEOs likely have different incentive, reputation, and career concerns. Gibbons and Murphy (1992) provide evidence on this. Therefore, we use the ratio of CEO tenure to CEO age as a measure of CEO quality, which will serve as an instrument for CEO ownership.

Treasury Stock: Palia (2001) suggests that a firm is most likely to buy back its stock when it believes the stock to underpriced relative to where the managers think the price should be. Thus, the level of treasury stock should be correlated with firm performance and firm value. We use the ratio of the treasury stock to total assets as the instrument for performance. ${ }^{9}$

Currently Active CEOs on Board: Hallock (1997) and Westphal and Khanna (2003) emphasize the role of networks among CEOs that serve on boards, and the adverse impact on the governance of such firms. Ex ante, there is no reason to believe that this variable will be correlated with firm performance. We consider the percentage of directors who are currently active CEOs as an instrument for governance.

Capital Structure instrument: We use the modified Altman's Z-score (1968) suggested in MacKie-Mason (1990) as the instrument for leverage. This measure is a proxy for financial distress; the lower the Z-score, the greater the probability of financial distress. We expect this variable to be positively correlated with leverage. ${ }^{10}$

Table 2 presents the descriptive statistics and sample sizes for the variables for all available years and for just 2002. Table 3 presents the parametric and non-parametric correlation coefficients among the performance and governance variables.

\section{B. Estimation Issues}

\footnotetext{
${ }^{9}$ We consider the sum of share repurchases during the past three years (as a fraction of total assets) as an alternative instrumental variable. The results are robust to this alternative specification.

${ }^{10}$ We also considered Graham's (1996) marginal tax rate as an instrument for leverage. The Stock and Yago (2004) test indicates that this is a weak instrument.
} 
The instruments for performance, governance, ownership and capital structure in equations (1a), (1b), (1c) and (1d) have been discussed above. Regarding the control variables: Prior literature, for example, Core, Holthausen and Larcker (1999), Gillan, Hartzell and Starks (2003), and Core, Guay and Rusticus (2005), suggests that industry performance, return volatility, growth opportunities and firm size are important determinants of firm performance. Yermack (1996) documents a relation between board size and performance. Demsetz (1983) suggests that small firms are more-likely to be closely-held suggesting a different governance structure than large firms. Firms with greater growth opportunities are likely to have different ownership and governance structures than firms with fewer growth opportunities; see, for example, Smith and Watts (1992), and Gillan, Hartzell and Starks (2003). Demsetz and Lehn (1985), among others, suggest a relation between information uncertainty about the firm as proxied by return volatility and its ownership and governance structures.

Given the abovementioned findings in the literature, in equation (1a), the control variables include industry performance, $\log$ of assets, $R \& D$ and advertising expenses to assets, board size, standard deviation of stock return over the prior five years, and the instrument is treasury stock to assets. In equation (1b), the control variables include R\&D and advertising expenses to assets, board size, standard deviation of stock return over the prior five years, and the instruments is percentage of directors who are active CEOs. In equation (1c), the control variables include log of assets, $R \& D$ and advertising expenses to assets, board size, standard deviation of stock return over the prior five years, and the instrument is CEO tenure to CEO age. In equation (1d), the control variables include industry leverage, log of assets, R\&D and advertising expenses to assets, standard deviation of stock return over the prior five years, and the instrument is Altman's modified Z-score.

We estimate this system using ordinary least squares (OLS), two-stage least squares (2SLS) to allow for potential endogeneity, and three-stage least squares (3SLS) to allow for potential endogeneity and cross-correlation between the equations. If any of the right-hand side 
regressors are endogenously determined, OLS estimates of (1) are inconsistent. ${ }^{11}$ Properly specified instrumental variables (IV) estimates such as the two stage least squares (2SLS) are consistent. The problem is which instruments to use, and how many instruments to use. Regarding the number of instruments, we know we must include at least as many instruments as we have endogenous variables. The asymptotic efficiency of the estimation improves as the number of instruments increases, but so does the finite-sample bias (Johnston and DiNardo 1997). Choosing "weak instruments" can lead to problems of inference in the estimation.

An instrument is "weak" if the correlation between the instruments and the endogenous variable is small. Nelson and Startz (1990) and Bound, Jaeger and Baker (1995) were among the first to discuss how instrumental variables estimation can perform poorly if the instruments are weak. Nelson and Startz show that the true distribution of the instrumental variables estimator may look nothing like the asymptotic distribution. Bound, Jaeger and Baker focus on two related problems. First, if the instruments and the endogenous variables are weakly correlated, then even a weak correlation between the instruments and the error in the original structural equation (which should be zero) can lead to large inconsistencies in the IV estimates; this is known as the "bias" issue related to weak instruments. Second, finite sample results can differ substantially from asymptotic theory. Specifically, IV estimates are generally biased in the same direction as OLS estimates, with the magnitude of this bias increasing as the $R^{2}$ of the first-stage regression between the instruments and the endogenous variable approaches zero; this is known as the "size" issue related to weak instruments.

\footnotetext{
${ }^{11}$ This point is made in most econometric textbooks; for example, Johnston and DiNardo (1997, page 153) state, "Under the classical assumptions OLS estimators are best linear unbiased. One of the major underpinning assumptions is the independence of regressors from the disturbance term. If this condition does not hold, OLS estimators are biased and inconsistent." Kennedy (2003, page 180) notes, "In a system of simultaneous equations, all the endogenous variables are random variables - a change in any disturbance term changes all the endogenous variables since they are determined simultaneously...As a consequence, the OLS estimator is biased, even asymptotically.” Maddala (1992, page 383) observes, “...the simultaneity problem results in inconsistent estimators of the parameters, when the structural equations are estimated by ordinary least squares (OLS)."
} 
More recently, Stock and Yogo (2004) formalize the definitions and provide tests to determine if instruments are weak. They introduce two alternative definitions of weak instruments. First, a set of instruments is weak if the bias of the instrumental variables estimator, relative to the bias of the OLS estimator, exceeds a certain limit $b$. Second, the set of instruments is weak if the conventional $\alpha$-level Wald test based on instrumental variables statistics has a size that could exceed a certain threshold $r$. These two definitions correspond to the "bias" and "size" problems mentioned earlier, and yield a set or parameters that define a "weak instruments set."

For a set of valid instruments, we need to compare the OLS estimates with the IV estimates to determine if IV estimation is necessary. To do this, we use the Hausman (1978) specification test alternatively known as the Wu-Hausman or Durbin-Wu-Hausman test. The test statistic is constructed as follows:

$$
h \equiv\left(\hat{\beta}_{O L S}-\hat{\beta}_{I V}\right)^{\prime}\left(\operatorname{var}\left(\hat{\beta}_{O L S}\right)-\operatorname{var}\left(\hat{\beta}_{I V}\right)\right)^{-1}\left(\hat{\beta}_{O L S}-\hat{\beta}_{I V}\right) .
$$

This statistic has a chi-square distribution with degrees of freedom equal to the number of potentially endogenous regressors. If the difference between the OLS and IV estimates is "large," we conclude that OLS is not adequate. We use this same test to compare OLS to 2SLS, OLS to 3SLS, and 2SLS to 3SLS. If the instruments are valid, we can use this test to determine which estimation method should be used. ${ }^{12}$

\section{Corporate Governance and Performance}

Table 4 summarizes our main results of the relationship between governance and performance. While previous studies have used both stock market based and accounting measures of performance, we primarily rely on accounting performance measures. Stock market based performance measures are susceptible to investor anticipation. If investors anticipate the corporate governance effect on performance, long-term stock returns will not be significantly

\footnotetext{
${ }^{12}$ By construction, if the IV variance is larger than the OLS variance, the test statistic will be negative. In this case, we rely on the OLS estimates because of the smaller variance.
} 
correlated with governance even if a significant correlation between performance and governance indeed exists. $^{13}$

In Table 4, Panels A through G, we report the results for the relationship between operating performance (ROA) and the following governance measures respectively: GIM index, BCF index, TCL index, Brown and Caylor index, stock ownership of the median board member, CEO-Chair duality, and board independence. In each panel we report the OLS, 2SLS, and 3SLS estimates of the equation in (1a); we perform Hausman (1978) tests to guide our choice of which set of estimates to consider for inference purposes. In each panel, we report three measures of operating performance: contemporaneous return-on-assets (ROA), next year's ROA, and next two years' ROA. Given that information needed to construct the various governance measures for a particular year are released to market participants some time during the first two quarters of the year, the impact of governance on performance will be observed on both the contemporaneous and subsequent operating performance. Core, Guay, and Rusticus (2005) consider just the next year's operating performance. However, it is possible that to the extent governance impacts performance, operating performance may be impacted for the next several years. For this reason, we also consider the next two years' operating performance.

Table 4, Panel A, highlights the relationship between the GIM governance index and operating performance (ROA). Consider the results under the "Next 1 Year Performance." The Hausman test suggests we consider the 2SLS estimates for inference. The Stock and Yogo (2004) test indicates that our instruments are appropriate. There is a significant negative correlation between the GIM index and next year's ROA. Given that lower GIM index numbers reflect stronger shareholder rights (better governance), the above results are consistent with a positive relation between good governance, as measured by GIM, and operating performance. Results using the contemporaneous operating performance are similar. This relation is negative but

\footnotetext{
${ }^{13}$ However, to aid the comparison of our results with the extant literature, in Table 4, Panel H, we report results considering stock return and Tobin's $Q$ as performance measures.
} 
insignificant when we consider the operating performance of the next two years. These results are consistent with GIM's finding of a positive relation between good governance and performance for the period 1990-1999, and extends their findings to the most recent period, 2000-2004.

However, it is important to note that GIM's finding of a positive relation between good governance and performance is based on long-term stock returns as the measure of performance, and does not take into account the endogeneity of the relationships among corporate governance, performance, capital structure, and corporate ownership structure. ${ }^{14}$ As noted above, if investors anticipate the effect of corporate governance on performance, long-term stock returns will not be significantly correlated with governance even if a significant correlation between performance and governance exists. Indeed, as the results in Table 4, Panel H, indicate there is no significant relation between GIM's measure of governance and next year's stock returns, or Tobin's Q. ${ }^{15}$

In Table 4, Panel B, we note the relationship between the BCF governance index and operating performance. Again, the Hausman test suggests we consider the 2SLS estimates for inference, and the Stock and Yogo (2004) test indicates that our instruments are appropriate. There is a significant negative correlation between the BCF index and next year's ROA. Similar to the GIM index, lower BCF index numbers reflect better governance; hence, these results are consistent with a positive relation between good governance, as measured by $\mathrm{BCF}$, and operating performance. Results using the contemporaneous and next two years' operating performance are similar. However, similar to GIM, BCF's finding of a positive relation between good governance and performance is based on long-term stock returns. The results in Table 4, Panel H, indicate

\footnotetext{
${ }^{14}$ Consistent with the findings reported here, Core, Guay and Rusticus (2005) also find a positive relation between the GIM index and next year's ROA. However, these authors do not take into account the endogeneity of the relationships among corporate governance, performance, capital structure, and corporate ownership structure.

${ }^{15}$ These findings are consistent with those of Core, Holthausen and Larcker (1999) who conclude that their governance measures "more consistently predict future accounting operating performance than future stock market performance."
} 
there is no significant relation between BCF's measure of governance and next year's stock returns, or Tobin's Q. ${ }^{16}$

The relation between TCL's measure of good governance and operating performance is detailed in Table 4, Panel C. While this relation is negative and statistically significant for the contemporaneous year, it is not significant for next year's and the next two years' operating performance.

Table 4, Panel D notes a negative but insignificant relation between Brown and Caylor's measure of good governance and operating performance. Since this index is available only for 2002 , and we have operating data only through 2003, we do not report the relation between this index and next two years' operating performance.

In Table 4, Panel E, we note the relation between the dollar value of the median director's stock ownership and operating performance. We find a significant and positive relation between the dollar value of the median director's stock ownership and contemporaneous and next year's operating performance. This relation is positive but insignificant when we consider the operating performance of the next two years.

The relation between CEO-Chair duality and operating performance is documented in Table 4, Panel F. CEO-Chair duality is negatively and significantly related to contemporaneous, next year's and next two years' operating performance. ${ }^{17}$ This result, along with the results for GIM and BCF, suggests that greater managerial control leads to worse future operating performance.

\footnotetext{
${ }^{16}$ For robustness, we also estimate the performance-governance relation for each of the seven governance measures using the fixed effects estimator. The results are consistent with the results reported here. One positive feature of panel data and the fixed effects estimator is that if there are firm-specific time-invariant omitted variables in the estimated equation, the coefficients are estimated consistently. However, if the omitted variables are not stationary over time, the fixed effects estimated coefficients are inconsistent; see Wooldridge (2002). When the omitted variables are non-stationary, the instrumental variable technique can yield consistent estimates if the instruments are valid. As noted above, we use the Stock and Yogo (2004) weak instruments test to ascertain the validity of the instruments used in Table 4.

${ }^{17}$ Note that the governance variable CEO-Chair duality is 1 if the CEO is Chair and 0 otherwise. Hence, a negative relation between CEO-Chair duality and performance is equivalent to a positive relation between CEO-Chair separation and performance.
} 
Table 4, Panel G, details the relation between board independence and performance. Board independence is negatively and significantly related to contemporaneous, next year's and next two years' operating performance. This result is surprising, especially considering the recent emphasis that has been placed on board independence by the NYSE and NASDAQ regulations; however, it is consistent with prior literature (for example, Hermalin and Weisbach (2003)).

In summary, these results demonstrate that certain complex measures of corporate governance - GIM and BCF - and certain simple measures - director ownership and CEO-chair separation - are positively associated with current and future operating performance. Other measures seem to be less reliable indicators of performance. ${ }^{18}$ It is also important to note that the estimation method used does matter in certain cases. For example, consider the performancegovernance relationships estimated in Table 4, Panel H. The OLS estimate indicates a significantly negative relation between the GIM index and next year's Tobin's Q. However, the 2SLS estimate is positive but statistically insignificant for next year's Tobin's Q. The Hausman (1978) specification test suggests that the 2SLS estimates are more appropriate for statistical inferences. Similarly, the OLS and 2SLS estimates for the relation between the BCF index and future Tobin's Q are statistically and economically different. Again, the Hausman (1978) specification test suggests that the 2SLS estimates are more appropriate for statistical inferences. For this reason, we believe it is important to rely on inferences after controlling for the endogeneity between governance and performance.

\section{A. Economic Significance of Impact of Governance on Performance}

Table 5 notes the elasticities for G-Index, E-Index, and median director ownership with respect to operating performance. We find that a $1 \%$ improvement in governance as measured by

\footnotetext{
${ }^{18}$ We find that the relation between the GIM governance index and abnormal stock returns (after adjusting for market, size, book-to-market, and momentum factors) is not robust to either the construction of the abnormal stock return, or the sample period. Detailed results will be provided on request.
} 
the G-Index is associated with a $0.854 \%$ change in operating performance in the current period, a $0.763 \%$ change in next year's operating performance, and a $0.287 \%$ change in the next two years' operating performance. The economic impacts for the E-Index and for director ownership are slightly lower for contemporaneous and next year's performance, and are about the same for the next two years' operating performance.

Table 2 indicates that the G-index and median director ownership are uncorrelated. This suggests that a composite measure of governance that combines the information contained in the G-index and median director ownership has the potential of being a more powerful predictor of operating performance, than either measure by itself. To ensure robustness, we consider the nonparametric (rank) information of these two governance measures. For each year, all firms are ranked from best to worst governed with respect to each of the two governance variables. We sum these two ranks to get a composite index (Composite G-Ownership index) for each year for each sample firm. ${ }^{19}$ We find that a $1 \%$ improvement in governance as measured by the composite index is associated with a $1.874 \%$ change in operating performance in the current period, a $1.567 \%$ change in next year's operating performance, and a $1.520 \%$ change in the next two years' operating performance.

\section{B. Robustness Checks}

\section{B.1. Validity and Strength of Instruments}

First, following the suggestion of Larcker and Rusticus (2005), we consider an alternate set of instruments in addition to the instruments noted above. For example, we consider (one year) lagged performance for performance, lagged ownership for ownership, and lagged leverage for leverage. Results using these instruments are consistent with the results reported above.

\footnotetext{
${ }^{19}$ Year 2002 has 1,301 sample firms, which means the highest possible Composite G-Ownership index is 2,602. The lowest possible Composite G-Ownership index is 2 . The actual composite governance index varies from a low of 40 to a high of 2,594. We consider the natural logarithm of the Composite GOwnership index because of its better distributional properties.
} 
We have conducted the Stock and Yogo (2004) test to ensure that our instruments are strong. There are two other weak instrument tests. First, Hahn and Hausman (2002) present a test similar in spirit to the Hausman (1978) specification test. Second, the Hansen-Sargan test regresses the second stage residuals on the full set of instruments, and uses the sample size times the uncentered $\mathrm{R}^{2}$ from the regression as the test statistic; see Davidson and MacKinnon (2004). If the system (1a) - (1d) is correctly specified, the asymptotic distribution of the test statistic is chisquare with degrees of freedom being the difference between the number of instruments and regressors. If the chi-square statistic in the Hansen-Sargan test does not reject the null hypothesis, this implies that the instruments are valid and the system (1a) - (1d) is correctly specified. We presented the Stock and Yogo test results above because, in our opinion, its test statistic is easier to interpret; also, the Stock and Yogo test is consistent with the motivation of the prior research on weak instruments; for example, see Bound, Jaeger and Baker (1995) or Staiger and Stock (1997). However, we also perform the Hahn and Hausman weak instrument test, and the HansenSargan overidentification test; inferences from these tests are consistent with the reported Stock and Yogo test results.

Third, following the suggestions of Stock, Wright and Yogo (2002) and Hall, Rudebusch and Wilcox (1996) we perform the Cragg-Donald test for model identification. The CraggDonald test indicates that our system of equations is well-specified.

Fourth, we perform the Anderson-Rubin test suggested by Dufour (1997) to test the joint significance of the set of endogenous variables in our system of equations. The Anderson-Rubin test supports the joint significance of our set of endogenous variables.

\section{B.2. $k$-class estimators}

In the case of simultaneously determined variables, 2SLS can address this problem by using instrumental variables to obtain a predicted value of the endogenous regressor $(Y)$, then 
using this predicted value in the structural equation $(\hat{Y})$. There are estimators other than the 2SLS estimator, such as the $k$-class estimator that can address the endogeneity problem. The $k$ class of estimators are instrumental variables estimators where the predicted values used in the second stage structural equation take a special form; see Kennedy (2003) and Guggenberger (2005):

$$
Y_{i}^{*}=(1-k) Y+k \hat{Y}
$$

For consistent estimates the probability limit of $k$ must equal $1 .{ }^{20}$

The results in Table 6 with $k=0$ and with $k=1$ are identical to the results in Table 4 , for OLS and 2SLS, respectively. Recall that in Table 4, we showed that, based on the Hausman specification test, 2SLS was preferred to OLS for all governance measures. This means that there is some bias or inconsistency in the OLS estimation that is causing the OLS and 2SLS estimations to be different. By scanning down each column in Table 6, it is apparent that the $k$ class estimators produce a very slow, non-linear progression from the OLS results to the 2SLS results. Using the Hausman (1978) specification test, we compare each sequential estimation. For every measure of governance, the Hausman specification test indicates that the $k=1.0$ results are different from the $k=0.9$ result. This suggests that only using $k=1.0$ (2SLS) produces estimates that are completely free of simultaneity bias. As long as there is any part of the actual endogenous regressor used in the second stage structural regression, which is the case for $k$ less than 1.0, the simultaneity bias causes the regression results to be inconsistent.

The results for $k$-class estimators and next year's operating performance, next two years' operating performance, stock return and Tobin's Q (for contemporaneous and for the two additional time periods) as the performance measures are consistent with the results reported in Table 4.

\footnotetext{
${ }^{20}$ Certain maximum likelihood estimators, such as the limited information maximum likelihood (LIML) and the full information maximum likelihood can also be included in the $k$-class. The results using these estimators are qualitatively similar to the 2SLS results.
} 


\section{B.3. Estimation of Standard Errors}

Standard econometric textbooks note that OLS standard errors are biased when the residuals are correlated. In panel data, such as the one we consider here, residuals for a particular firm may be correlated across years, or for a particular year the residuals may be correlated across the sample firms. Two recent papers, Petersen (2005) and Wooldridge (2004) provide a careful analysis of the impact of correlated residuals on the bias in standard errors in panel data. We consider the suggestions of these authors in considering the robustness of our estimated performance-governance relationship to alternative standard error estimation methods. Petersen (2005) notes, "In the presence of a fixed firm effect both OLS and Fama-MacBeth standard error estimates are biased down significantly. Clustered standard errors which account for clustering by firm produce estimates which are unbiased." Table 7, Panel A, summarizes the performancegovernance relationship using OLS and clustered (Rogers) standard errors; these results are qualitatively similar to those in Table 4.

While Petersen's work is quite helpful in understanding the standard error estimates for a single equation model, it is unclear how his conclusions might apply to a system of simultaneous equations. Note that both the economics and econometrics of the performance-governance relationship as analyzed above strongly suggests that this relationship needs to be estimated as a system of simultaneous equations as in (1a), (1b), (1c), and (1d). We estimate the performancegovernance relationship using 2SLS and heteroscedasticity adjusted White and clustered (Rogers) standard errors, respectively. Also, we estimate the performance-governance relationship using OLS with fixed effects estimator including firm and year fixed effects, and OLS with fixed effects estimator with clustered (Rogers) standard errors, respectively. These results are consistent with those reported earlier and are summarized in Table 7, Panel B.

\section{B.4. Alternative Measures of Leverage}


It is possible that the results reported above regarding the performance-governance relation are sensitive to the construction of the leverage variable. In the capital structure literature, there does not appear to be any agreed upon measure of leverage. For our primary analyses, we use the measure that appears frequently in corporate finance studies: All long term debt divided by assets. To test the sensitivity of our results to this definition of leverage, we run the analyses in Table 4 using five alternative definitions of leverage:

debt.)

$$
\frac{\text { LongTermDebt }}{\text { TotalAssets }}
$$

(This is used in Table 4 - includes current portion of long term

$$
\begin{aligned}
& \frac{\text { LongTermDebt }}{\text { TotalAssets }} \quad \text { (Excluding current portion of long term debt.) } \\
& \frac{\text { TotalAssets - BookEquity }}{\text { TotalAssets }} \\
& \frac{\text { TotalBookLiabilities }}{\text { TotalAssets }} \\
& \left.\frac{\text { TotalAssets - BookEquity }}{\text { TotalAssets }} \quad \text { (Per, Baker \& Wurgler (2002). }{ }^{21}\right) \\
& \frac{\text { BookDebt }}{\text { TotalAssets - BookEquity + MarketEquity }} \text { (Per, Baker \& Wurgler (2002).) }
\end{aligned}
$$

We find that our results regarding the relation between performance and governance are robust to alternative definitions of leverage.

\section{Corporate Governance and Management Turnover}

The preceding analysis focused on the relation between governance and performance generally. However, governance scholars and commentators suggest that governance is especially critical in imposing discipline and providing fresh leadership when the corporation is performing particularly poorly. It is possible that governance matters most in only certain firm events, such

\footnotetext{
${ }^{21}$ Definitions (3) and (5) differ in the Compustat variables used, specifically for Book Equity. Definition (3) uses Compustat data item \#216, "Stockholders' Equity." Definition (5) defines Book Equity as total assets less total liabilities (item 181) and preferred stock (item 10) plus deferred taxes (item 35) and convertible debt (item 79). The correlation between the leverage variables based on the two definitions is 0.90 .
} 
as the decision to change senior management. For this reason, we study the relationship between governance, performance, and CEO turnover.

Using Compustat's Execucomp database, we identify 1,923 CEO changes from 1993 to 2003. Table 8 documents the number of disciplinary and non-disciplinary CEO turnovers during this period. Our criteria for classifying a CEO turnover as disciplinary or non-disciplinary is similar to that of Weisbach (1988), Gilson (1989), Huson, Parrino, and Starks (2001), and Farrell and Whidbee (2003). CEO turnover is classified as "non-disciplinary" if the CEO died, if the CEO was older than 63, if the change was the result of an announced transition plan, or if the CEO stayed on as chairman of the board for more than a year. CEO turnover is classified as "disciplinary" if the CEO resigned to pursue other interests, if the CEO was terminated, or if no specific reason is given.

We consider a multinomial logit regression. ${ }^{22}$ The dependent variable is equal to 0 if no turnover occurred in a firm-year, 1 if the turnover was disciplinary, and 2 if the turnover was nondisciplinary. We consider the past two years' stock return as the performance measure. We estimate the following baseline equation:

Type of CEO Turnover $=g_{1}\left(\right.$ Past 2 years' stock return, $\left.Z_{1}, \varepsilon_{1}\right)$.

The $Z_{1}$ vector of controls includes CEO ownership, CEO age, CEO tenure, firm size, industry return and year dummy variables. These control variables are motivated by a substantial extant literature on performance and CEO turnover; for example, see Huson, Parrino, and Starks (2001), Farrell and Whidbee (2003), and Engel, Hayes and Wang (2003). To determine the role that governance plays in CEO turnover, we create an interactive variable that is equal to (Past 2 years' stock return $x$ Governance). The reason behind this is that if the firm is performing adequately, good governance should not lead to CEO turnover; only when performance is poor do we expect

\footnotetext{
${ }^{22}$ We also considered a fixed effects logit estimator model. However, there are concerns regarding the bias of such an estimator. Greene (2004) documents that when the time periods in panel data are five or less (as is the case in this study), nonlinear estimation may produce coefficients that can be biased in the range of $32 \%$ to $68 \%$.
} 
better governed firms to be more likely to replace the CEO. To measure this effect, we estimate the following modified version of equation (2a):

Type of CEO Turnover $=g_{2}$ (Past 2 years' stock return, Governance,

(Past 2 years' stock return $x$ Governance), $Z_{1}, \varepsilon_{2}$ ).

Table 9 highlights the relation between different measures of governance and disciplinary CEO turnover. Table 9, Panel A, details the multinomial logit regression results for the determinants of disciplinary CEO turnover. Consider first the baseline results without governance variables in the regression. The baseline results indicate that a firm's stock market returns during the previous two years, CEO stock ownership, and CEO tenure are significantly negatively related to disciplinary CEO turnover; these findings are consistent with the prior literature noted above. Interestingly, we find that the prior two years' returns of similar firms in the industry is significantly positively related to disciplinary CEO turnover.

Does good governance have an impact on disciplinary CEO turnover directly, or is governance related to disciplinary turnover only in poorly performing companies? The results in Table 9, Panel A, shed light on this question. Note that when the governance variables are included, the prior return variable is not significant in five of the seven cases, suggesting that bad performance alone is not enough to lead to a change in senior management. Also note that the governance variable by itself is statistically not significant in most cases. ${ }^{23}$ This suggests that good governance per se is not related to disciplinary turnover. The coefficient of the interactive term (Past 2 years' stock return $x$ Governance) sheds light on the question whether governance is related to disciplinary turnover only for poorly performing firms. The interactive term suggests that good governance as measured by the dollar value of the median director's stock ownership and the percentage of directors who are independent, increases the probability of disciplinary

\footnotetext{
${ }^{23}$ When the CEO is also the Chairman, he is less likely to experience disciplinary turnover.
} 
turnover for poorly performing firms. ${ }^{24} 25$ Both the GIM and BCF measures of good governance are negatively related to the probability of disciplinary turnover for poorly performing firms. This suggests that better governed firms as measured by the GIM and BCF indices are less likely to experience disciplinary management turnover in spite of their poor performance. Finally, when the CEO is also the Chairman, he is more likely to experience disciplinary turnover given poor firm performance.

Table 9, Panel B, details the multinomial logit regression results for the determinants of non-disciplinary CEO turnover. We do not expect any relation between good governance and non-disciplinary CEO turnover both unconditionally, and conditional on poor prior performance; the results in Panel B are consistent with this.

\section{A. Robustness Checks}

First, we have highlighted above the endogenous relationships among corporate governance, performance, capital structure, and corporate ownership structure. It is possible that management turnover and performance (and ownership) are also endogenous. To address turnover endogeneity we estimate a system of five equations: $1 \mathrm{a}, 1 \mathrm{~b}, 1 \mathrm{c}, 1 \mathrm{~d}$, and $2 \mathrm{~b} .{ }^{26}$ Motivated by the findings of Fich and Shivdasani (2005) we use percentage of board members who are on more than four boards as instrument for CEO Turnover; the Stock-Yogo (2002) test, the Hahn and Hausman (2002) test and the Hansen-Sargan test suggest that this is an appropriate

\footnotetext{
${ }^{24}$ The finding of the probability of disciplinary CEO turnover (given poor prior firm performance) increasing with greater board independence is consistent with the extant literature, for example, see Fich and Shivdasani (2005), and Weisbach (1988).

${ }^{25}$ The economic importance of the dollar ownership of the median director is greater than board independence. We calculate the predicted probability of disciplinary and non-disciplinary turnover, using the coefficient estimates from Table 9. When all parameters are measured at their mean values, the probability of disciplinary turnover is $2.28 \%$ with the dollar ownership of the median director as the governance variable; this increases to $12.55 \%$ when the (Past Return $x$ Director \$ Ownership) interaction term decreases by one standard deviation. The corresponding probabilities are $2.90 \%$ and $7.96 \%$ for board independence.

${ }^{26}$ Woolridge (2002) cautions about the two-stage estimation procedure when the dependent variable in one of the equations is dichotomous. However, on the basis of the evidence in Angrist (2001) and Alvarez and Glasgow (1999) we interpret the signs of the two-stage estimates in the usual way.
} 
instrument. Results from taking turnover endogeneity into account are entirely consistent with the disciplinary turnover results noted in Table 9, Panel A.

Second, due to data limitations the sample periods and sample sizes for the various governance measures are different in Table 9, Panels A and B. It is possible that the significant relationship between a governance measure and disciplinary turnover in a poorly performing firm may be sample-period specific, or is being influenced by the different sample sizes. To address this concern, we consider disciplinary turnovers only for the period 2000 through 2002 for all governance measures. The results are consistent with the results reported above. ${ }^{27}$

Third, for reasons noted in section IV.B.3. (page 23) above, we computed the clustered (Rogers) standard errors for the coefficients in the CEO turnover model; the results are consistent with those reported in Table 9.

Fourth, it is possible that the board considers industry adjusted performance instead of firm performance in deciding whether to discipline the CEO. Results considering industry adjusted performance are similar to that reported above.

\section{Summary and Conclusions}

Our primary contribution to the literature is the consistent estimation of the relationship between corporate governance and performance, by taking into account the inter-relationships among corporate governance, corporate performance, corporate capital structure, and corporate ownership structure. We make four additional contributions to the literature:

First, instead of considering just a single measure of governance (as prior studies in the literature have done), we consider seven different governance measures. We find that better governance as measured by the GIM and BCF indices, stock ownership of board members, and CEO-Chair separation is significantly positively correlated with better contemporaneous and

\footnotetext{
${ }^{27}$ Motivated by the findings of Huson, Parrino and Malatesta (2004) we also controlled for turnovers as a consequence of takeover pressure and other types of forced turnover. The results are qualitatively similar to that noted above.
} 
subsequent operating performance. Also, interestingly, board independence is negatively correlated with contemporaneous and subsequent operating performance. This is especially relevant in light of the prominence that board independence has received in the recent NYSE and NASDAQ corporate governance listing requirements. We conduct a battery of robustness checks including (a) consideration of alternate instruments for estimating the system of equations, (b) consideration of diagnostic tests to ensure that our instruments are valid and our system of equations is well-identified, and (c) alternative estimates of the standard errors of our model's estimated coefficients. These robustness checks provide consistent results and increase our confidence in the performance-governance relation as noted above.

Second, contrary to claims in the literature, none of the governance measures are correlated with future stock market performance. In several instances inferences regarding the (stock market) performance and governance relationship do depend on whether or not one takes into account the endogenous nature of the relationship between governance and (stock market) performance. For example, the OLS estimate indicates a significantly negative relation between the GIM index and next year's Tobin's Q, and the GIM index. However, the 2SLS estimate is positive but statistically insignificant for next year's Tobin's Q. The Hausman (1978) specification test suggests that the 2SLS estimates are more appropriate for statistical inferences. The 2SLS results suggest no relationship between the GIM index and future Tobin's Q. For this reason, we believe it is important to rely on inferences after controlling for the endogeneity between governance and performance.

Third, given poor firm performance, the probability of disciplinary management turnover is positively correlated with stock ownership of board members, and with board independence. However, better governed firms as measured by the GIM and BCF indices are less likely to experience disciplinary management turnover in spite of their poor performance.

Fourth, this study proposes a governance measure, namely, dollar ownership of the board members, that is simple, intuitive, less prone to measurement error, and not subject to the 
problem of weighting a multitude of governance provisions in constructing a governance index. Consideration of this governance measure by future accounting, finance, and corporate law researchers would enhance the comparability of research findings.

Can a single board characteristic be as effective a measure of corporate governance as indices that consider multiple measures of corporate charter provisions, management compensation structure, and board characteristics? Corporate boards have the power to make, or at least, ratify all important decisions including decisions about investment policy, management compensation policy, and board governance itself. It is plausible that board members with appropriate stock ownership will have the incentive to provide effective monitoring and oversight of important corporate decisions noted above; hence board ownership can be a good proxy for overall good governance. Furthermore, the measurement error in measuring board ownership can be less than the total measurement error in measuring a multitude of board processes, compensation structure, and charter provisions. Finally, while board characteristics, corporate charter provisions, and management compensation features do characterize a company's governance, construction of a governance index requires that the above variables be weighted. The weights a particular index assigns to individual board characteristics, etc. is important. If the weights are not consistent with the weights used by informed market participants in assessing the relation between governance and firm performance, then incorrect inferences would be made regarding the relation between governance and firm performance.

The above findings have important implications for researchers, senior policy makers, and corporate boards: Efforts to improve corporate governance should focus on stock ownership of board members - since it is positively related to both future operating performance, and to the probability of disciplinary management turnover in poorly performing firms. Finally, our recommendations on incentive effects of board stock ownership are consistent with the implications of Hermalin and Weisbach (2007). 
Proponents of board independence should note with caution the negative relation between board independence and future operating performance. Hence, if the purpose of board independence is to improve performance, then such efforts might be misguided. However, if the purpose of board independence is to discipline management of poorly performing firms, then board independence has merit. Finally, even though the GIM and BCF good governance indices are positively related to future operating performance, policy makers and corporate boards should be cautious in their emphasis on the components of these indices since this might exacerbate the problem of entrenched management, especially in those situations where management should be disciplined, that is, in poorly performing firms.

\section{References}

Altman, Edward I., 1968, Financial Ratios, discriminates analysis, and the prediction of corporate bankruptcy, Journal of Finance 23, 589-609.

Alvarez, R. and G. Glasgow, 1999, Two-stage estimation of non-recursive choice models, California Institute of Technology working paper.

Anderson, Ronald C., Sattar A. Mansi and David M. Reeb, 2004, Board characteristics, accounting report integrity, and the cost of debt, Journal of Accounting and Economics 37, 315-342.

Angrist, J., 2001. Estimation of limited dependent variable models with dummy endogenous regressors: Simple strategies for empirical practice, Journal of Business and Economic Statistics 19, 2-16.

Ashbaugh-Skaife, Hollis, Daniel W. Collins and Ryan LaFond, 2006, The effects of corporate governance on firms' credit ratings, Journal of Accounting and Economics, forthcoming.

Bergstresser, Daniel and Thomas Philippon, CEO incentives and earnings management, Journal of Financial Economics 80, 511-530.

Baker, M. and J. Wurgler, 2002, Market timing and capital structure, Journal of Finance 57, 1-32.

Barber, Brad and John Lyon, 1996, Detecting abnormal operating performance: The empirical power and specification of test statistics, Journal of Financial Economics 41, 359-400.

Bebchuk, Lucian, Alma Cohen, and Allen Ferrell, 2004, What matters in corporate governance?, Working paper, Harvard Law School

Bebchuk, Lucian and Alma Cohen, 2005, The costs of entrenched boards, Journal of Financial Economics $78,409-433$.

Berle, A.A. and G. Means, 1932, The Modern Corporation and Private Property, Macmillan, New York. 
Bhagat, Sanjai and Bernard Black, 2002, The non-correlation between board independence and long term firm performance, Journal of Corporation Law 27, 231-274.

Bhagat, Sanjai, Dennis Carey and Charles Elson, 1999, Director ownership, corporate performance, and management turnover, The Business Lawyer 54.

Black, Bernard, 1990, Shareholder passivity reexamined, Michigan Law Review 89, 2550.

Bound, John, David A. Jaeger, and Regina M. Baker, 1995, Problems with instrumental variables estimation when the correlation between the instruments and the endogenous explanatory variable is weak, Journal of the American Statistical Association 90, 443-450.

Bowen, Robert M., Shivaram Rajgopal and Mohan Venkatachalam, 2005, Accounting discretion, corporate governance, and firm performance, University of Washington working paper.

Brickley, James A., Jeffrey L. Coles, and Gregg Jarrell, 1997, Leadership structure: Separating the CEO and chairman of the board, Journal of Corporate Finance, 3, 189-220.

Brown, Lawrence D. and Marcus L. Caylor, 2004, Corporate governance and firm performance, Georgia State University working paper.

Bushman, Robert, Qi Chen, Ellen Engel and Abbie Smith, 2004, Financial accounting information, organizational complexity and corporate governance systems, Journal of Accounting and Economics 37, 1670201.

Carhart, Mark M., 1997, On persistence in mutual fund performance, Journal of Finance 52(1), 57-82.

Core, John E., Wayne R. Guay, Tjomme O. Rusticus, Does weak governance cause weak stock returns? An examination of firm operating performance and investors' expectations, Journal of Finance, Forthcoming, 2005.

Core, John E., Robert W. Holthausen, and David F. Larcker, 1999, Corporate governance, chief executive officer compensation, and firm performance, Journal of Financial Economics 51, 371-406.

Cragg, John G. and Stephen G. Donald, 1993, "Testing Identifiability and Specification in Instrumental Variable Models," Econometric Theory 9, 222-240.

Cremers, Martijn K.J., and Vinay B. Nair, 2005, Governance mechanisms and equity prices, Journal of Finance 60, 2859-2894.

Davidson, Russell, and James G. MacKinnon, 2004, Estimation and Inference in Econometrics, Oxford University Press, New York.

Defond, Mark L., Rebecca N. Hann and Xuesong Hu, 2005, Does the market value financial expertise on audit committees of boards of directors? Journal of Accounting Research 43, 153-193.

Demsetz, Harold, 1983, The structure of ownership and the theory of the firm, Journal of Law and Economics 26, 375-390.

Demsetz, Harold and Kenneth Lehn, 1985, The structure of corporate ownership: Causes and consequences, Journal of Political Economy 33, 3-53.

Dufour, J., 1997, Some impossibility theorems in econometrics, with applications to structural and dynamic models, Econometrica 65, 1365-1389. 
Engel, Ellen, Rachel M. Hayes, and Xue Wang, 2003, CEO turnover and properties of accounting information, Journal of Accounting and Economics 36, 197-226.

Erickson, Merle, Michelle Hanlon and Edward L. Maydew, 2006, Is there a link between executive equity incentives and accounting fraud? Journal of Accounting Research 44, 113-143.

Fama, Eugene F., 1980, Agency problems and the theory of the firm, Journal of Political Economy 88, 288307.

Farell, K.A. and Whidbee, D.A., 2003, The impact of firm performance expectations on CEO turnover and replacement decisions, Journal of Accounting and Economics 36, 165-196.

Fich, Eliezer M. and Anil Shivdasani, Are busy boards effective monitors?, Journal of Finance, Forthcoming, 2005.

Gibbons, Robert and Murphy, Kevin J, 1992. Optimal incentive contracts in the presence of career concerns: Theory and evidence," Journal of Political Economy 100(3), 468-505.

Gillan, Stuart L., Jay C. Hartzell, Laura T. Starks, 2003, Industries, investment opportunities and corporate governance structures, Working paper.

Gillan, Stuart L., Recent developments in corporate governance: An overview, Journal of Corporate Finance 12, 381-402.

Gompers, Paul A., Joy L. Ishii, and Andrew Metrick, 2003, Corporate governance and equity prices, Quarterly Journal of Economics 118(1), 107-155.

Gilson, Stuart C., 1989, Management turnover and financial distress, Journal of Financial Economics 25, 241-262.

Graham, J.R., 1996, Proxies for the corporate marginal tax rate, Journal of Financial Economics 42, 187221.

Graham, J.R., M.H. Lang and D. A. Shackelford, 2004, Employee stock options, corporate taxes, and debt policy, Journal of Finance 59, 1585-1618.

Greene, William H., 2004, The Behavior of the Fixed Effects Estimator in Nonlinear Models, The Econometrics Journal 7.

Grossman, Sanford and Oliver D. Hart, 1983, An analysis of the principal-agent problem, Econometrica , 51 , no $1,7-45$.

Grossman, Sanford and Oliver D. Hart, 1986, The costs and benefits of ownership: A theory of vertical and lateral integration, Journal of Political Economy 44, 691-719.

Graham, John R, 1996, Debt and the marginal tax rate, Journal of Financial Economics 41, 41-73.

Guggenberger, Patrick, 2005, Finite-sample evidence suggesting a heavy tail problem of the generalized empirical likelihood estimator, UCLA Department of Economics working paper.'

Hahn, Jinyong and Jerry A. Hausman, 2002, A new specification test for the validity of instrumental variables, Econometrica 70, 163-189.

Hall, A., G. Rudebusch and D. Wilcox, 1996, Judging instrument relevance in instrumental variables estimation, International Economic Review 37, 283-298. 
Hallock, Kevin F., 1997, Reciprocally interlocking boards of directors and executive compensation, Journal of Financial and Quantitative Analysis 32, 331-344.

Harris, Milton, and Artur Raviv, 1988, Corporate control contests and capital structure, Journal of Financial Economics 20, 55-86.

Hart, Oliver D. and John Moore, 1990, Property rights and the theory of the firm, Journal of Political Economy 48, 1119-1158.

Hausman, Jerry A., 1978, Specification tests in econometrics, Econometrica 46, 1251-1271.

Hermalin, Benjamin E. and Michael S. Weisbach,, 1998, Endogenously chosen boards of directors and their monitoring of the CEO, American Economic Review 88, 96-118.

Hermalin, Benjamin and Michael Weisbach, 2003, Boards of directors as an endogenously determined institution: A survey of the economic evidence. Economic Policy Review, 9: 7-26.

Hermalin, Benjamin and Michael Weisbach, 2007, Transparency and corporate governance, University of California and University of Illinois working paper.

Hermes Pensions Management, 2005, Corporate governance and performance, Lloyds Chambers, London, U.K.

Himmelberg, Charles P., R. Glenn Hubbard, and Darius Palia, 1999, Understanding the determinants of managerial ownership and the link between ownership and performance, Journal of Financial Economics 53, 353-384.

Huson, Mark R. Robert Parrino and Laura T. Starks, 2001, Internal monitoring mechanisms and CEO turnover: A long-term perspective, Journal of Finance 54(6), 2265-2297.

Huson, Mark R., Paul H. Malatesta and Robert Parrino, 2004, Managerial succession and firm performance, Journal of Financial Economics 74, 237-275.

Jensen, Michael, 1986, Agency costs of free cash flow, corporate finance, and takeovers, American Economic Review 76, 323-329.

Jensen, Michael, and William Meckling, 1976, Theory of the firm: Managerial behavior, agency costs, and ownership structure, Journal of Financial Economics 3, 305-360.

Jensen, Michael, and Jerold B. Warner, 1988, The distribution of power among corporate managers, shareholders and directors, Journal of Financial Economics 20, 3-24.

Johnston, Jack and John DiNardo, 1997, Econometric Methods, Fourth edition, The McGraw-Hill Companies.

Kennedy, Peter, 2003, A Guide to Econometrics, Fifth Edition, MIT Press.

Khanna, N. and S. Tice, 2005, Pricing, exit, and location decisions of firms: Evidence on the role of debt and operating efficiency, Journal of Financial Economics 75, 397-428.

Larcker, David F. and Rusticus, Tjomme O., 2005, On the use of instrumental variables in accounting research, Stanford University working paper.

Linck, James S., Jeffry M. Netter and Tina Yang, 2005, The determinants of board structure, University of Georgia working paper. 
MacKie-Mason, Jeffrey K., 1990, Do taxes affect corporate financing decisions? Journal of Finance 45, 1471-1493.

Maddala, G.S., 1992, Introduction to Econometrics, Second Edition, MacMillan.

Milanovic, Branko, Do more unequal countries redistribute more? Does the median Voter hypothesis hold?, World Bank policy research working paper series, Carnegie Endowment for International Peace, 2004

Morck, Randall, Andrei Shleifer, and Robert W. Vishny, 1988, Management ownership and market valuation, Journal of Financial Economics 20, 293-315.

Myerson, Roger, 1987, Incentive compatibility and the bargaining problem, Econometrica 47, 61-73.

Nelson, Charles R. and Richard Startz, 1990, Some further results on the exact small sample properties of the instrumental variables estimator, Econometrica 58, 967-976.

Novaes, Walter, and Luigi Zingales, 1999, Capital structure choice under a takeover threat, University of Chicago working paper.

Palia, Darius, 2001, The endogeneity of managerial compensation in firm valuation: A solution, Review of Financial Studies 14, 735-764.

Petersen, Mitchell A., 2005, Estimating standard errors in finance panel data sets: Comparing approaches, Nortwestern University working paper.

Roe, Mark J., 1994, Strong managers, weak owners: The political roots of American corporate finance, Princeton University Press, Princeton, NJ.

Shleifer, Andrei and Kevin M. Murphy, Persuasion in politics, American economic association papers and proceedings, Vol. 94, No. 2, May 2004

Smith, Clifford W. and Ross L. Watts, 1992, The investment opportunity set and corporate financing, dividend and compensation policies, Journal of Financial Economics 32, 263-292.

Staiger, Douglas and James H. Stock, 1997, "Instrumental Variables Regression with Weak Instruments," Econometrica 65(3), 557-586.

Stock, James H., and Motohiro Yogo, 2004, "Testing for weak instruments in linear IV regression, in D.W.K. Andrews and J.H. Stock, eds., Identification and Inference for Econometric Models: Essays in Honor of Thomas J. Rothenberg. Cambridge: Cambridge University Press.

Stock, J., J. Wright and M. Yogo, 2002, A survey of weak instruments and weak identification in generalized method of moments, Journal of Business and Economic Statistics 20, 518-529.

Stulz, Rene M, 1988, Managerial control of voting rights: Financing policies and the market for corporate control, Journal of Financial Economics 20, 25-54.

Westphal, James D. and Poonam Khanna, 2003, Keeping Directors in Line: Social Distancing as a Control Mechanism in the Corporate Elite, Administrative Science Quarterly 48, 361-398.

Weisbach, Michael S., 1988, Outside directors and CEO turnover, Journal of Financial Economics 20, 432460.

Wooldridge, J.M., 2002, Econometric Analysis of Cross Section and Panel Data, MIT Press, Cambridge, Massachusetts. 
Wooldridge, J.M., 2004, Cluster sample methods in applied econometrics, Michigan State University working paper.

Yermack, David, 1996, Higher market valuation for firms with a small board of direcxtors, Journal of Financial Economics 40, 185-211.

Yermack, David, 2006, Flights of fancy: Corporate jets, CEO perquisites, and inferior shareholder returns, Journal of Financial Economics 80, 211-242. 


\section{TABLE 1}

\section{Description of Variables}

This table presents descriptions of variables used in this study. It also shows the years for which we have data available and the total number of observations we have of each variable. The full sample period is from 1990 to 2004.

\begin{tabular}{l} 
Panel A: Governance Variables \\
\hline (A) $\quad$ GIM G-Index \\
The G-Index is constructed from data compiled by the Investor Responsibility Research Center ("IRRC"), as described in \\
Gompers, Ishii, Metrick (2003). A firm's score is based on the number of shareholder rights-decreasing provisions a firm \\
has. The index ranges from a feasible low of 0 to a high of 24. A high G-Score is associated with weak shareholder \\
rights, and a low G-Score is associated with high shareholder rights. \\
BCF E-Index \\
The E-Index is constructed from IRRC data as described in Bebchuk, Cohen, Ferrell (2004). It uses a 6-provision subset \\
of the G-Index. The index ranges from a feasible low of 0 to a high of 6; a high score is associated with weak shareholde \\
rights and a low score is associated with high shareholder rights. \\
TCL Benchmark Score \\
The Corporate Library is an independent investment research firm providing corporate governance data, analysis \& risk \\
assessment tools. The benchmark score is based on the following criteria: whether the board is classified, whether the \\
outside directors constitute a majority on the board, whether the board has an independent chairman or lead director, \\
whether the audit committee consists of only independent directors, whether the board has adopted a formal governance \\
policy, number of directors with more than fifteen years tenure, number of directors who serve on more than four boards, \\
number of directors older than seventy years old, and CEO compensation structure. The index ranges from a feasible low \\
of 0 to a high of 100. This data was provided to us by TCL. For more information, see www.thecorporatelibrary.com.
\end{tabular}

(D) BC GovScore

The GovScore is constructed from data compiled by Institutional Shareholder Services ("ISS"), as described in Brown,

Caylor (2004). Fifty-two firm characteristics and provisions are used to assign a score to each firm. The feasible range of

scores is from 0 to 52 . A high score is associated with better corporate governance. 
TABLE 1 (Continued)

Description of Variables

Panel A: Governance Variables (continued)

(E) Board Independence

The number of unaffiliated independent directors divided by the total number of board members. In some cases, we use

Sample Size

the INDEP measure from Bhagat, Black (2001). This measure is constructed from data provided by IRRC and TCL.

(F) Median Director Dollar Value Ownership

The dollar value of the stock ownership / voting power is calculated for all directors. We take the median director's

holdings as the governance measure as this individual can be viewed as having the 'swing' vote in governance related matters. This variable is calculated from data provided by IRRC and TCL.

(G) Median Director Percent Value Ownership

The percentage ownership of the firm's total voting power is calculated for all directors. We take the median director's ownership as the governance measure as this individual can be viewed as having the 'swing' vote in governance related matters. This variable is calculated from data provided by IRRC and TCL.

(H) CEO Chair-Duality

A dummy variable equal to 1 if the $\mathrm{CEO}$ is also the chairman of the board. This measure is constructed from data provided by IRRC and TCL.

1996-2003

9,317

Alternative Governance Measures

In some anslyses, we consider six alternative measures of corporate governance: (1) the percentage of directors who are currently active CEOs, (2) the percentage of directors currently serving on more than four boards, (3) the percentage of directors who have served on the sample firm's board for more than fifteen years, (4) the percentage of directors who are older than seventy years old, (5) the percentage of directors who are women, and (6) the percentage of directors who do

not own any stock in the sample firm.

(A) Return on Assets

We measure ROA as operating income divided by end of year total assets (Compustat data item 6). In general, following

1990-2004

Barber and Lyon (1996), we use operating income before depreciation (Compustat data item 13). Unless otherwise

noted, this is our measure for ROA. In some cases, we use operating income after depreciation (Compustat data item

178). These cases are pointed out explicitly.

(B) Stock Return

We use the CRSP monthly stock file to calculate one-year compound returns, including dividends.

1990-2004

16,936

(C) Tobin's Q

We use the Tobin's Q measure as in Gompers, Ishii and Metrick(2003): (Book Value of Assets + Market Value of

$1990-2004$

17,587

Common Stock - Book Value of Common Stock - Deferred Taxes) / Book Value of Assets.

1990-2004 16,228 -

For ROA and Tobin's Q, we use the average measure for years t-2 and t-1. For Stock Return, we use the one-year compound return for years $\mathrm{t}-2$ and $\mathrm{t}-1$.

(E) Industry Performance

For all industry performance measures, we calculate the mean performance for each SIC four-digit classification. We do this for ROA, return, and Tobin's Q as discussed above. One-year and two-year performance is calculated as above. 
TABLE 1 (Continued)

Description of Variables

\begin{tabular}{|c|c|c|c|}
\hline \multicolumn{2}{|c|}{ Panel C: Other Endogenous Variables } & $\begin{array}{c}\text { Years } \\
\text { Available }\end{array}$ & $\begin{array}{l}\text { Sample } \\
\text { Size }\end{array}$ \\
\hline \multirow[t]{2}{*}{ (A) } & $\underline{\text { CEO Ownership }}$ & & \\
\hline & $\begin{array}{l}\text { The percent of the firm's stock owned by the CEO. This variable is constructed from the Execucomp database and } \\
\text { provided by TCL. }\end{array}$ & $\begin{array}{l}1992- \\
2003\end{array}$ & 13,044 \\
\hline \multirow[t]{2}{*}{ (B) } & Leverage & & \\
\hline & Long term debt (data item 9) / Total Assets (data item 6). & $\begin{array}{l}1990- \\
2004\end{array}$ & 17,438 \\
\hline \multicolumn{2}{|c|}{ Panel D: Other Variables } & $\begin{array}{c}\text { Years } \\
\text { Available }\end{array}$ & $\begin{array}{l}\text { Sample } \\
\text { Size }\end{array}$ \\
\hline \multirow[t]{2}{*}{$(\mathrm{A})$} & $\underline{\text { Assets }}$ & & \\
\hline & Compustat data item 6 & $\begin{array}{l}1990- \\
2004\end{array}$ & 24,255 \\
\hline \multirow[t]{2}{*}{ (B) } & $\underline{\text { Expenses }}$ & & \\
\hline & $\begin{array}{l}\text { R\&D and Advertising Expenses / Total Assets. R\&D is Compustat data item } 46 \text { and advertising is data item } 45 \text {. } \\
\text { Similar to Palia (2001), we use a dummy variable to identify firms for which this variable is not missing. }\end{array}$ & $\begin{array}{l}1990- \\
2004\end{array}$ & 21,230 \\
\hline \multirow[t]{2}{*}{ (C) } & Board Size & & \\
\hline & The total number of directors, obtained from IRRC and TCL. & $\begin{array}{l}1996- \\
2003\end{array}$ & 17,993 \\
\hline \multirow[t]{2}{*}{ (D) } & $\underline{\text { CEO Age }}$ & & \\
\hline & The age of the CEO, obtained from Execucomp and TCL. & $\begin{array}{l}1992- \\
2003\end{array}$ & 10,990 \\
\hline \multirow[t]{2}{*}{$(\mathrm{E})$} & CEO Tenure & & \\
\hline & The number of years the CEO has been CEO, obtained from Execucomp and TCL. & $\begin{array}{c}1992- \\
2003\end{array}$ & 10,651 \\
\hline \multirow[t]{2}{*}{$(\mathrm{F})$} & $\underline{\text { Director Age }}$ & & \\
\hline & The median director's age, obtained from IRRC and TCL. & $\begin{array}{c}1998- \\
2003\end{array}$ & 15,360 \\
\hline \multirow[t]{2}{*}{$(\mathrm{G})$} & $\underline{\text { Director Tenure }}$ & & \\
\hline & The number of years the median director has been on the board, obtained from IRRC and TCL. & $\begin{array}{c}1998- \\
2003\end{array}$ & 15,360 \\
\hline$(\mathrm{H})$ & The standard deviation of the monthly stock return for the five preceding years. & $\begin{array}{c}1990- \\
2004\end{array}$ & 15,272 \\
\hline
\end{tabular}




\section{TABLE 2}

Descriptive Statistics

This table presents the mean, median and number of observations for the primary performance, governance and control variables used in this study. Statistics for all available years and for 2002 only are presented.




TABLE 3

Correlation Coefficients

This table presents the correlation coefficients for the performance and governance variables. The performance variables are in Panel A and the governance variables are in Panel B. The Pearson correlation coefficients are above the diagonal and the Spearman rank correlation coefficients are below the diagonal. Significant coefficients at the $1 \%, 5 \%$, and $10 \%$ levels are noted by $* * *, * *$ and $*$, respectively.

\section{Panel A:}

\begin{tabular}{l|ccc}
\hline & Return & ROA & Tobin's Q \\
\hline Return & & $0.345^{* * * *}$ & $0.475^{* * *}$ \\
ROA & $0.321^{* * *}$ & & $0.196 * * *$ \\
Tobin's Q & $0.58 * * *$ & $0.251 * * *$ & \\
\hline
\end{tabular}

Panel B:

\begin{tabular}{|c|c|c|c|c|c|c|c|}
\hline & $\begin{array}{l}\text { GIM G- } \\
\text { Index }\end{array}$ & $\begin{array}{l}\text { BCF E- } \\
\text { Index }\end{array}$ & $\begin{array}{c}\text { TCL } \\
\text { Benchmark } \\
\text { Score }\end{array}$ & $\begin{array}{c}\text { BC } \\
\text { GovScore }\end{array}$ & $\begin{array}{l}\% \text { Inde- } \\
\text { pendent }\end{array}$ & $\begin{array}{l}\text { Director } \\
\text { Holdings }\end{array}$ & $\begin{array}{l}\text { CEO-Chair } \\
\text { Duality }\end{array}$ \\
\hline GIM G-Index & & $0.719 * * *$ & $-0.327 * * *$ & $-0.105 * * *$ & $0.275 * * *$ & 0.005 & $0.088 * * *$ \\
\hline BCF E-Index & $0.726 * * *$ & & $-0.358 * * *$ & $-0.161 * * *$ & $0.263 * * *$ & $-0.083 * * *$ & $0.062 * *$ \\
\hline $\begin{array}{l}\text { TCL Benchmark } \\
\text { Score }\end{array}$ & $-0.343 * * *$ & $-0.377 * * *$ & & $0.314 * * *$ & $0.088 * * *$ & $-0.116 * * *$ & $-0.201 * * *$ \\
\hline BC GovScore & $-0.11 * * *$ & $-0.169 * * *$ & $0.311 * * *$ & & $0.354 * * *$ & -0.013 & $0.089 * * *$ \\
\hline$\%$ Independent & $0.286 * * *$ & $0.263 * * *$ & $0.069 * *$ & $0.345^{* * *}$ & & $-0.147 * * *$ & $0.183 * * *$ \\
\hline Director Holdings & 0.013 & $-0.073 * * *$ & $-0.125 * * *$ & -0.032 & $-0.141 * * *$ & & $0.043 *$ \\
\hline CEO-Chair Duality & $0.09 * * *$ & $0.068 * *$ & $-0.179 * * *$ & $0.078 * *$ & $0.194 * * *$ & $0.048 *$ & \\
\hline
\end{tabular}




\section{TABLE 4}

Panels A-G: Simultaneous Equations System Estimation, Performance Measured by Return on Assets

Panel H: Simultaneous Equations System Estimation, Performance Measured by Return on Assets, Stock Return, and Tobin’s Q

This table presents the coefficient estimates for performance, governance, CEO ownership, and leverage as estimated in the following system:

(1a) Performance $=f_{1}$ (Ownership, Governance, Leverage, Log(Assets), Industry Performance, $($ R $\& D$ and

Advertising Expenses) / Assets, Board Size, Stock Volatility, Treasury Stock / Assets, $\left.\varepsilon_{1}\right)$,

(1b) Governance $=f_{2}$ (Performance, Ownership, Leverage, (R\&D and Advertising Expenses) / Assets, Board

Size, Stock Volatility, Active CEOs on Board, $\left.\varepsilon_{2}\right)$

(1c) Ownership $=f_{3}$ (Performance, Governance, $\log ($ Assets), Leverage, (R\&D and Advertising Expenses) /

Assets, Board Size, Stock Volatility, CEO Tenure / CEO Age, $\left.\varepsilon_{3}\right)$

(1d) Leverage $=f_{4}$ (Performance, Governance, Ownership, Industry Leverage, Log(Assets), (R\&D and Advertising Expenses) / Assets, Board Size, Stock Volatility, Altman's Z-Score, $\varepsilon_{4}$ )

Only the coefficients for governance, CEO ownership and leverage from the first equation (1a) are presented in Panels A-G since this is the primary relationship that this study is concerned with. Performance is measured by Return on Assets ("ROA"). Ownership is measured by the percent of stock owned by the CEO at time $t$ in all panels ("CEO Own"). Leverage is measured as long term debt to assets. Governance is measured by a different variable in each panel. All governance variables are as of time $t$. In Panel A, the Gompers, Ishii and Metrick (2003) G-Index is used as the governance variable. In Panel B, the Bebchuk, Cohen and Ferrell (2004) EIndex is used as the governance variable. In Panel C, TCL Benchmark score is used as the governance variable. In Panel D, the Brown and Caylor (2004) GovScore is used as the governance variable (data is available only for 2002). In Panel E, the dollar value of the median director's stock holdings is used as the governance variable. In Panel F, a dummy variable equal to 1 if the CEO is also the Chair of the board, 0 otherwise, is used as the governance variable. In Panel G, the percent of directors who are independent is used as the governance variable. Results are presented using performance in time $t, t+1$, and $t+1$ to $t+2$. Each system is estimated using OLS, 2SLS, and 3SLS. The Hausman (1978) specification test is performed on each system to determine which estimation method is most appropriate. The null hypothesis is that the methods are equivalent, so the null is rejected for high $h$-statistics. The Stock and Yogo (2004) test for weak instruments is also performed. The F-statistics from the first-stage regression for each of the three potentially endogenous regressors in equation (1a) - Ownership, Governance and Leverage - are presented. If the F-statistic exceeds the critical value (using 5\% bias) from Stock and Yogo (2004), the instruments are deemed to be valid. The number of observations used in each panel-performance period varies so to maximize the sample size for the panel-performance period. Coefficient estimates are presented, with $p$-values in parentheses.

In Panel $H$, the results from the previous seven panels are summarized. The results are presented using next year's Return on Assets as the performance measure, for all seven governance variables and for all three estimation methods. The results using next year's stock return and next year's Tobin's $Q$ are also presented. Only the coefficient estimate on the governance variable is presented; $p$-values are in parentheses. The estimation method deemed most appropriate by the Hausman (1978) specification test is in bold. 


\section{Contemporaneous Performance}

$\begin{array}{llcc}\underline{\text { OLS }} & & \frac{p-}{\text { Estimate }} & \frac{\text { value }}{(0.10)} \\ & \text { Gov } & -0.001 & (0.01) \\ & \text { CEO Own } & 0.053 & (0.00) \\ & \text { Leverage } & -0.061 & \\ \underline{\text { RSLS }}= & & & \\ & \text { Gov } & -0.013 & (0.01) \\ & \text { CEO Own } & 0.185 & (0.02) \\ & \text { Leverage } & -0.045 & (0.00) \\ \text { 3SLS } & & & \\ & & & \\ & \text { Gov } & -0.013 & (0.01) \\ & \text { CEO Own } & 0.191 & (0.02) \\ & \text { Leverage } & -0.045 & (0.00)\end{array}$

Sample Size

4,600

\section{Hausman (1978) Specification Test:}

$\begin{array}{lcc} & h \text {-statistic } & p \text {-value } \\ \text { OLS v. 2SLS } & 66.84 & (0.00) \\ \text { OLS v. 3SLS } & 48.79 & (0.01) \\ \text { 2SLS v. 3SLS } & 19.96 & (0.87)\end{array}$

\section{Stock and Yogo (2004) Weak Instruments Test:}

$\begin{array}{lccc} & \begin{array}{c}\text { First-Stage } \\ \text { F-Statistic }\end{array} & & \begin{array}{c}\text { Critical } \\ \text { Value }\end{array} \\ \text { Gov } & 35.52 & & 9.53 \\ \text { CEO Own } & 215.21 & & 9.53 \\ \text { Leverage } & 98.74 & & 9.53\end{array}$

Next 1 Year Performance

\begin{tabular}{|c|c|}
\hline Estimate & $\begin{array}{c}p- \\
\text { value }\end{array}$ \\
\hline-0.001 & (0.03) \\
\hline 0.073 & $(0.00)$ \\
\hline-0.035 & $(0.00)$ \\
\hline
\end{tabular}

$\underline{\text { 2SLS }}$

$\mathrm{ROA}=$

Gov

CEO Own

Leverage

$-0.011$

0.326

$-0.014$

3SLS

ROA $=$

Gov

CEO Own

Leverage

$-0.01$

0.334

$-0.014$

4,561

Sample Size

\begin{tabular}{|c|c|}
\hline$h$-statistic & $p$-value \\
\hline 78.62 & $(0.00)$ \\
\hline 69.29 & $(0.00)$ \\
\hline 18.09 & $(0.92)$ \\
\hline
\end{tabular}

OLS v. 2SLS

OLS v. 3SLS

2SLS v. 3SLS
Next 2 Years Performance

\section{$\underline{\text { OLS }}$}

$\mathrm{ROA}=$

$(0.00)$

$\begin{array}{lcc} & \text { Estimate } & \text { p-value } \\ \text { Gov } & -0.001 & (0.02) \\ \text { CEO Own } & 0.021 & (0.10) \\ \text { Leverage } & -0.040 & (0.00)\end{array}$

\section{SLS}

$\mathrm{ROA}=$

Gov

CEO Own

Leverage

$-0.004$

0.093

$-0.032$

$(0.16)$

(0.00)

3SLS

ROA $=$

Gov

CEO Own

Leverage

$-0.004$

0.098

$-0.032$

(0.15)

(0.06)

(0.00)
Sample Size $\quad 3,416$

OLS v. 2SLS

OLS v. 3SLS

2SLS v. 3SLS $\underline{h \text {-statistic }}$ 37.69

103.40

31.63 $p$-value

(0.10)

(0.00)

(0.29)

Gov
CEO Own
Leverage

First-Stage Critical

$\frac{F \text {-Statistic }}{34.02} \quad \frac{\text { Value }}{9.53}$

$\begin{array}{cc}34.02 & 9.53 \\ 232.02 & 9.53 \\ 106.98 & 9.53\end{array}$

First-Stage Critical

Gov

CEO Own

Leverage

\begin{tabular}{|c|c|}
\hline F-Statistic & Value \\
\hline 24.76 & 9.53 \\
\hline 172.11 & 9.53 \\
\hline 87.70 & 9.53 \\
\hline
\end{tabular}




\section{Contemporaneous Performance}

\begin{tabular}{|c|c|c|}
\hline OLS & & Estimate \\
\hline \multirow[t]{3}{*}{$\overline{\mathrm{ROA}}=$} & Gov & -0.004 \\
\hline & CEO Own & 0.042 \\
\hline & Leverage & -0.059 \\
\hline \multicolumn{3}{|l|}{$2 \mathrm{SLS}$} \\
\hline \multirow[t]{2}{*}{$\mathrm{ROA}=$} & Gov & -0.034 \\
\hline & CEO Own & 0.066 \\
\hline
\end{tabular}

\section{$\underline{3 S L S}$}

$\overline{\mathrm{ROA}}=$

Leverage

$-0.038$

$\begin{array}{lcc}\text { Gov } & -0.037 & (0.00) \\ \text { CEO Own } & 0.076 & (0.49) \\ \text { Leverage } & -0.038 & (0.00)\end{array}$

Sample Size

4,600

\section{Hausman (1978) Specification Test:}

$\begin{array}{lcc} & \frac{h \text {-statistic }}{74.15} & \frac{p \text {-value }}{(0.00)} \\ \text { OLS v. 2SLS } & 174.70 & (0.00) \\ \text { OLS v. 3SLS } & 132.80 & (0.00)\end{array}$

\section{Stock and Yogo (2004) Weak Instruments Test:}

$\begin{array}{lccc} & \begin{array}{c}\text { First-Stage } \\ \text { F-Statistic }\end{array} & \begin{array}{c}\text { Critical } \\ \text { Value }\end{array} \\ \text { CEV Own } & 35.03 & & 9.53 \\ \text { Leverage } & 215.21 & & 9.53 \\ & 98.74 & & 9.53\end{array}$

Next 1 Year Performance

Next 2 Years Performance
$(0.00)$

\section{$\underline{\text { OLS }}$}

$\mathrm{ROA}=$

$(0.00)$

\section{$\underline{\text { 2SLS }}$}

$\mathrm{ROA}=$

(1)

\section{$\underline{\text { 3SLS }}$}

$\mathrm{ROA}=$

$(0.49)$

$\begin{array}{lccc} & \text { Estimate } & & \frac{p-}{\text { value }} \\ \text { Gov } & -0.005 & & (0.00) \\ \text { CEO Own } & 0.061 & (0.00) \\ \text { Leverage } & -0.033 & (0.00)\end{array}$

$\begin{array}{lll}\text { Gov } & -0.031 & (0.02) \\ \text { CEO Own } & 0.211 & (0.07) \\ & -0.008 & (0.43)\end{array}$

Leverage

$-0.008$

(0.43)

Gov

CEO Own

Leverage

$-0.03$

$-0.032$

0.223

$-0.008$

$(0.01)$
$(0.05)$
$(0.43)$

Sample Size

4,561

$$
\begin{gathered}
\frac{h \text {-statistic }}{96.53} \\
244.20 \\
138.60
\end{gathered}
$$$$
\text { OLS v. 2SLS }
$$

OLS v. 3SLS

2SLS v. 3SLS

$\frac{p \text {-value }}{(0.00)}\left(\begin{array}{c}(0.00) \\ (0.00)\end{array}\right.$

$\underline{\mathrm{OLS}}$

2SLS

$\begin{array}{lcc} & \text { Estimate } & \text { p-value } \\ \text { Gov } & -0.002 & (0.00) \\ \text { CEO Own } & 0.015 & (0.22) \\ \text { Leverage } & -0.039 & (0.00)\end{array}$

Go

CEO Own

Leverage

$-0.015$

0.025

$-0.028$

(0.07)

$\mathrm{ROA}=$

3SLS

$\frac{\mathrm{BS}}{\mathrm{ROA}}=$

Gov

CEO Own

Leverage

$-0.017$

0.033

$-0.028$

(0.04)

$(0.67)$

(0.00)
Sample Size $\quad 3,416$

OLS v. 2SLS

OLS v. 3SLS

2SLS v. 3SLS
40.19

92.33

152.60 $p$-value

(0.06)

$(0.00)$

\begin{tabular}{|c|c|c|}
\hline & $\begin{array}{l}\text { First-Stage } \\
F \text {-Statistic }\end{array}$ & $\begin{array}{c}\text { Critical } \\
\text { Value }\end{array}$ \\
\hline Gov & 32.63 & 9.53 \\
\hline CEO Own & 232.05 & 9.53 \\
\hline Leverage & 106.98 & 9.53 \\
\hline
\end{tabular}

(0.00)$$
98.74
$$

\begin{tabular}{cc}
$\begin{array}{c}\text { First-Stage } \\
\text { F-Statistic }\end{array}$ & $\begin{array}{c}\text { Critical } \\
\text { Value }\end{array}$ \\
\hline 23.90 & 9.53 \\
172.11 & 9.53 \\
87.70 & 9.53
\end{tabular}




\section{Contemporaneous Performance}

\section{Next 1 Year Performance}

\section{$\underline{\text { OLS }}$}

$\underline{\mathrm{ROA}}=$

$\begin{array}{lcc} & \underline{\text { Estimate }} & \begin{array}{c}\underline{p-} \\ \text { value }\end{array} \\ \text { Gov } & 0.000 & (0.05) \\ \text { CEO Own } & 0.067 & (0.03) \\ \text { Leverage } & -0.043 & (0.00)\end{array}$

\section{$\underline{2 S L S}$}

$\mathrm{ROA}=$

Gov

CEO Own

Leverage

$-0.005$

$-0.089$

$-0.038$

$\underline{3 S L S}$

$\overline{\mathrm{ROA}}=$

$\begin{array}{lll}\text { Gov } & -0.005 & (0.04) \\ \text { CEO Own } & -0.090 & (0.62) \\ \text { Leverage } & -0.038 & (0.01)\end{array}$

2,199

\section{Hausman (1978) Specification Test:}

$\begin{array}{lcc} & h \text {-statistic } & p \text {-value } \\ \text { OLS v. 2SLS } & 38.24 & (0.09) \\ \text { OLS v. 3SLS } & -5.26 & - \\ \text { 2SLS v. 3SLS } & 0.65 & (1.00)\end{array}$

\section{Stock and Yogo (2004) Weak Instruments Test:}

$\begin{array}{lcc} & \text { First-Stage } & \text { Critical } \\ \text { Gov } & \underline{F-S t a t i s t i c} & \underline{\text { Value }} \\ \text { CEO Own } & 25.58 & 9.53 \\ \text { Leverage } & 102.33 & 9.53 \\ & 37.91 & 9.53\end{array}$

Sample Size

\begin{tabular}{|c|c|c|c|}
\hline OLS & & Estimate & $p$-valu \\
\hline \multirow[t]{3}{*}{$\overline{\mathrm{ROA}}=$} & Gov & 0.000 & $(0.26)$ \\
\hline & CEO Own & 0.073 & $(0.02)$ \\
\hline & Leverage & -0.015 & $(0.23)$ \\
\hline \multicolumn{4}{|l|}{$\underline{2 S L S}$} \\
\hline \multirow[t]{3}{*}{$\overline{\mathrm{ROA}}=$} & Gov & -0.003 & $(0.27)$ \\
\hline & CEO Own & 0.133 & $(0.45)$ \\
\hline & Leverage & -0.004 & $(0.77)$ \\
\hline \multicolumn{4}{|l|}{ 3SLS } \\
\hline \multirow[t]{3}{*}{$\mathrm{ROA}=$} & Gov & -0.003 & $(0.26)$ \\
\hline & CEO Own & 0.135 & $(0.45)$ \\
\hline & Leverage & -0.004 & $(0.76)$ \\
\hline
\end{tabular}

Sample Size

2,138

$\begin{array}{cc}h \text {-statistic } & p \text {-value } \\ 31.96 & (0.28) \\ 11.88 & (1.00) \\ 1.01 & (1.00)\end{array}$

OLS V. 2SLS

OLS v. 3SLS

2SLS v. 3SLS

1.01

$(1.00)$

\begin{tabular}{cc}
$\begin{array}{cc}\text { First-Stage } \\
\text { F-Statistic }\end{array}$ & $\begin{array}{c}\text { Critical } \\
\text { Value }\end{array}$ \\
\hline 20.40 & 9.53 \\
100.48 & 9.53 \\
48.38 & 9.53
\end{tabular}

Gov

CEO Own

Leverage
Next 2 Years Performance

\begin{tabular}{|c|c|c|c|}
\hline \multirow{4}{*}{$\frac{\text { OLS }}{\text { ROA }}=$} & & Estimate & p-valu \\
\hline & Gov & 0.000 & $(0.56)$ \\
\hline & CEO Own & 0.013 & $(0.60)$ \\
\hline & Leverage & -0.036 & $(0.00)$ \\
\hline \multicolumn{4}{|l|}{ 2SLS } \\
\hline \multirow[t]{3}{*}{$\mathrm{ROA}=$} & Gov & -0.002 & $(0.21)$ \\
\hline & CEO Own & -0.037 & $(0.78)$ \\
\hline & Leverage & -0.032 & $(0.00)$ \\
\hline \multicolumn{4}{|l|}{ 3SLS } \\
\hline \multirow[t]{3}{*}{$\overline{\mathrm{ROA}}=$} & Gov & -0.002 & $(0.22)$ \\
\hline & CEO Own & -0.049 & $(0.71)$ \\
\hline & Leverage & -0.032 & $(0.00)$ \\
\hline
\end{tabular}

$\begin{array}{lcc} & h \text {-statistic } & p \text {-value } \\ \text { OLS v. 2SLS } & 14.64 & (0.98) \\ \text { OLS v. 3SLS } & 79.79 & (0.00) \\ \text { 2SLS v. 3SLS } & 8.00 & (1.00)\end{array}$

Gov

CEO Own

First-Stage Critical

Leverage

$\underline{\text { Value }}$

$13.85 \quad 9.53$

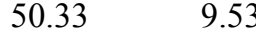

$27.16 \quad 9.53$

Sample Size $\quad 977$ 


\begin{tabular}{|c|c|c|c|}
\hline$\underline{\text { OLS }}$ & & $\underline{\text { Estimate }}$ & $\begin{array}{c}p- \\
\text { value }\end{array}$ \\
\hline \multirow[t]{3}{*}{$\mathrm{ROA}=$} & Gov & 0.000 & (0.53) \\
\hline & CEO Own & -0.141 & $(0.00)$ \\
\hline & Leverage & -0.041 & $(0.01)$ \\
\hline
\end{tabular}

\section{$\underline{\text { 2SLS }}$}

$\mathrm{ROA}=$

$\begin{array}{lcc}\text { Gov } & -0.004 & (0.60) \\ \text { CEO Own } & 0.211 & (0.30) \\ \text { Leverage } & -0.032 & (0.09)\end{array}$

\section{SLS}

$\widehat{\mathrm{ROA}}=$

Gov
CEO Own
Leverage

Sample Size

811

\section{Hausman (1978) Specification Test:}

$\begin{array}{lcc} & h \text {-statistic } & p \text {-value } \\ \text { OLS v. 2SLS } & 14.60 & (0.98) \\ \text { OLS v. 3SLS } & 6.63 & (1.00) \\ \text { 2SLS v. 3SLS } & 24.11 & (0.68)\end{array}$

\section{Stock and Yogo (2004) Weak Instruments Test:}

$\begin{array}{lcc} & \begin{array}{c}\text { First-Stage } \\ \text { F-Statistic }\end{array} & \begin{array}{c}\text { Critical } \\ \text { Value }\end{array} \\ \text { CEO Own } & 8.40 & \\ \text { Leverage } & 28.53 & 9.53 \\ & 17.06 & 9.53\end{array}$

\section{Next 1 Year Performance}

Next 2 Years Performance

\section{$\underline{\text { OLS }}$}

$\widehat{\mathrm{ROA}}=$

\begin{tabular}{|c|c|c|}
\hline & Estimate & $\begin{array}{c}p- \\
\text { value }\end{array}$ \\
\hline Gov & $\overline{0.000}$ & $\overline{(0.85)}$ \\
\hline CEO Own & 0.087 & $(0.05)$ \\
\hline Leverage & -0.032 & (0.08) \\
\hline
\end{tabular}

$\underline{\text { 2SLS }}$

$\mathrm{ROA}=$

Gov

CEO Own $\quad 0.057 \quad(0.82)$

Leverage

$-0.024 \quad(0.29)$

3SLS

$\mathrm{ROA}=$

Gov

CEO Own

Leverage

$-0.005 \quad(0.65)$

$0.007 \quad(0.98)$

$-0.024 \quad(0.27)$
773

$\begin{array}{lcc} & \underline{h \text {-statistic }} & p \text {-value } \\ \text { OLS v. 2SLS } & 10.92 & (1.00) \\ \text { OLS v. 3SLS } & 71.82 & (0.00) \\ \text { 2SLS v. 3SLS } & -1.39 & -\end{array}$

$\begin{array}{lccc} & \begin{array}{c}\text { First-Stage } \\ \text { F-Statistic }\end{array} & & \begin{array}{c}\text { Critical } \\ \text { Value }\end{array} \\ { } } & 6.05 & & 9.53 \\ \text { CEO Own } & 30.23 & & 9.53 \\ \text { Leverage } & 19.04 & & 9.53\end{array}$




\section{Contemporaneous Performance}

\begin{tabular}{|c|c|c|}
\hline OLS & & Estimate \\
\hline \multirow[t]{3}{*}{$\overline{\mathrm{ROA}}=$} & Gov & 0.011 \\
\hline & CEO Own & 0.047 \\
\hline & Leverage & -0.038 \\
\hline \multicolumn{3}{|l|}{ 2SLS } \\
\hline \multirow[t]{2}{*}{$\mathrm{ROA}=$} & Gov & 0.006 \\
\hline & CEO Own & 0.211 \\
\hline
\end{tabular}

\section{$\underline{\text { 3SLS }}$}

$\widehat{\mathrm{ROA}}=$

$\begin{array}{lcc}\text { Gov } & 0.005 & (0.02) \\ \text { CEO Own } & 0.179 & (0.00) \\ \text { Leverage } & -0.038 & (0.00)\end{array}$

Sample Size

5,101

\section{Hausman (1978) Specification Test:}

$\begin{array}{lcc} & \frac{h \text {-statistic }}{127.70} & p \text {-value } \\ \text { OLS v. 2SLS } & (0.00) \\ \text { OLS v. 3SLS } & -2123.00 & - \\ \text { 2SLS v. 3SLS } & 1407.00 & (0.00)\end{array}$

\section{Next 1 Year Performance}

(0.00)

$(0.00)$

\section{Stock and Yogo (2004) Weak Instruments Test:}

\begin{tabular}{|c|c|c|}
\hline & $\begin{array}{l}\text { First-Stage } \\
\text { F-Statistic }\end{array}$ & $\begin{array}{c}\text { Critical } \\
\text { Value }\end{array}$ \\
\hline Gov & 180.22 & 9.53 \\
\hline CEO Own & 250.54 & 9.53 \\
\hline Leverage & 96.51 & 9.53 \\
\hline
\end{tabular}

\section{$\underline{\text { OLS }}$}

$\mathrm{ROA}=$

\section{$\underline{\text { 2SLS }}$}

$\mathrm{ROA}=$

$\begin{array}{lc} & \underline{\text { Estimate }} \\ \text { Gov } & 0.010 \\ \text { CEO Own } & 0.050 \\ \text { Leverage } & -0.018 \\ & \\ \text { Gov } & 0.005 \\ \text { CEO Own } & 0.287 \\ \text { Leverage } & -0.017 \\ & \\ \text { Gov } & 0.004 \\ \text { CEO Own } & 0.206 \\ \text { Leverage } & -0.015 \\ & \\ 5,053 & \\ & \\ 148.60 & (0.00) \\ 1.75 & (1.00) \\ 6.64 & (1.00)\end{array}$

OLS v. 2SLS

OLS v. 3SLS

2SLS v. 3SLS

$\frac{p-}{\text { value }}$
$(0.00)$
$(0.01)$
$(0.03)$

3SLS

$\widehat{\mathrm{ROA}}=$

Sample Size
Next 2 Years Performance $\underline{\text { OLS }}$

$\mathrm{ROA}=$

$0.03)$

2SLS

$\mathrm{ROA}=$

$(0.00)$

$(0.06)$

\section{$(0.08)$}

$(0.00)$

(0.09)

\section{SLS}

$\underline{\mathrm{ROA}}=$
CEO

CEO Own

Leverage

$\begin{array}{cc}\text { Estimate } & \frac{p \text {-value }}{0.004} \\ 0.013 & (0.00) \\ (0.32)\end{array}$

CEO Own $\quad 0.013 \quad(0.32)$

Leverage $\quad-0.034 \quad(0.00)$

$\begin{array}{lcc}\text { Gov } & 0.002 & (0.16) \\ \text { CEO Own } & 0.112 & (0.01) \\ \text { Leverage } & -0.032 & (0.00)\end{array}$

Sample Size $\quad 3,814$

$\begin{array}{lcc} & h \text {-statistic } & p \text {-value } \\ \text { OLS v. 2SLS } & 42.93 & (0.04) \\ \text { OLS v. 3SLS } & 17.29 & (0.94) \\ \text { 2SLS v. 3SLS } & -16.70 & -\end{array}$

$\begin{array}{ccc}\begin{array}{cc}\text { First-Stage } \\ \text { F-Statistic }\end{array} & & \begin{array}{c}\text { Critical } \\ \text { Value }\end{array} \\ 185.11 & & 9.53 \\ 257.66 & & 9.53 \\ 107.23 & & 9.53\end{array}$

\begin{tabular}{|c|c|}
\hline $\begin{array}{l}\text { First-Stage } \\
\text { F-Statistic }\end{array}$ & $\begin{array}{c}\text { Critical } \\
\text { Value }\end{array}$ \\
\hline 139.53 & 9.53 \\
\hline 197.45 & 9.53 \\
\hline 92.74 & 9.53 \\
\hline
\end{tabular}




\section{Contemporaneous Performance}

\begin{tabular}{|c|c|c|c|}
\hline OLS & & Estimate & $\frac{p-}{\text { value }}$ \\
\hline \multirow[t]{3}{*}{$\mathrm{ROA}=$} & Gov & 0.002 & $\overline{(0.47)}$ \\
\hline & CEO Own & 0.076 & $(0.00)$ \\
\hline & Leverage & -0.054 & $(0.00)$ \\
\hline
\end{tabular}

\section{$\underline{\text { 2SLS }}$}

$\mathrm{ROA}=$

$\begin{array}{lcc}\text { Gov } & -0.029 & (0.00) \\ \text { CEO Own } & 0.348 & (0.00) \\ \text { Leverage } & -0.043 & (0.00)\end{array}$

\section{$\underline{\text { 3SLS }}$}

$\widehat{\mathrm{ROA}}=$

$\begin{array}{lcc}\text { Gov } & -0.028 & (0.00) \\ \text { CEO Own } & 0.328 & (0.00) \\ \text { Leverage } & -0.041 & (0.00)\end{array}$

Sample Size

5,101

\section{Hausman (1978) Specification Test:}

$\begin{array}{lcc} & \frac{h \text {-statistic }}{126.10} & \frac{p \text {-value }}{(0.00)} \\ \text { OLS v. 2SLS } & -539.00 & - \\ \text { OLS v. 3SLS } & -26.10 & -\end{array}$

2SLS v. 3SLS

$-26.10$

Stock and Yogo (2004) Weak Instruments Test:

\begin{tabular}{|c|c|c|}
\hline & $\begin{array}{l}\text { First-Stage } \\
\text { F-Statistic }\end{array}$ & $\begin{array}{c}\text { Critical } \\
\text { Value }\end{array}$ \\
\hline Gov & 164.59 & 9.53 \\
\hline CEO Own & 250.54 & 9.53 \\
\hline Leverage & 96.51 & 9.53 \\
\hline
\end{tabular}

\begin{tabular}{|c|}
\hline Next 1 Year Performance \\
\hline
\end{tabular}

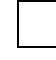

$\underline{\text { OLS }}$ $\overline{\mathrm{ROA}}=$

$\begin{array}{lcc}\text { Gov } & \text { Estimate } & \frac{p-}{\text { value }} \\ \text { CEO Own } & 0.000 & (0.88) \\ \text { Leverage } & 0.079 & (0.00) \\ & -0.033 & (0.00)\end{array}$

\section{$\underline{\text { 2SLS }}$}

$\mathrm{ROA}=$

CEO Own

Leverage

$-0.029$

0.418

$-0.017$

\section{SLS}

$\widehat{\mathrm{ROA}}=$

$\begin{array}{lcc}\text { Gov } & -0.028 & (0.00) \\ \text { CEO Own } & 0.394 & (0.00) \\ \text { Leverage } & -0.016 & (0.07)\end{array}$

Sample Size

5,053

$\begin{array}{lcc} & \frac{h \text {-statistic }}{} & \frac{p \text {-value }}{(0.00)} \\ \text { OLS v. 2SLS } & 158.10 & (1.00) \\ \text { OLS v. 3SLS } & 0.16 & - \\ \text { 2SLS v. 3SLS } & -39.30 & \end{array}$

OLS v. 3SLS

$-39.30$

First-Stage

$\frac{\text { F-Statistic }}{177.21}$

Gov

CEO Own

Leverage

$\begin{array}{ll}257.71 & 9.53 \\ 107.47 & 9.53\end{array}$

Next 2 Years Performance

$(0.00)$

(0.06)

$\underline{\mathrm{OLS}}$

2SLS

$\mathrm{ROA}=$

\section{$\underline{\text { 3SLS }}$}

$\mathrm{ROA}=$

(1)

Sample Size

3,814

OLS v. 2SLS

OLS v. 3SLS

2SLS v. 3SLS

$\begin{array}{cc}\frac{h \text {-statistic }}{78.00} & \frac{p \text {-value }}{(0.00)} \\ -64.00 & - \\ 6.59 & (1.00)\end{array}$

First-Stage Critical

Gov $\frac{\text { F-Statistic }}{164.80} \quad \frac{\text { Value }}{9.53}$

CEO Own

Leverage
Estimate $p$-value

$-0.004 \quad(0.04)$

$0.026 \quad(0.04)$

$-0.039 \quad(0.00)$

$\begin{array}{lcc}\text { Gov } & -0.017 & (0.00) \\ \text { CEO Own } & 0.142 & (0.00) \\ \text { Leverage } & -0.034 & (0.00)\end{array}$

Gov

CEO Own

$-0.017$

(0.00)

Leverage

$-0.033$

$(0.00)$ 


\section{Contemporaneous Performance}

$\begin{array}{llcc}\underline{\text { OLS }} & & \underline{\text { Estimate }} & \frac{p-}{\text { value }} \\ & \text { Gov } & -0.045 & (0.00) \\ & \text { CEO Own } & 0.049 & (0.01) \\ & \text { Leverage } & -0.055 & (0.00)\end{array}$

\section{$\underline{\text { 2SLS }}$}

$\mathrm{ROA}=$

$\begin{array}{lcc}\text { Gov } & -0.131 & (0.00) \\ \text { CEO Own } & 0.083 & (0.32) \\ \text { Leverage } & -0.054 & (0.00)\end{array}$

\section{$\underline{\text { SSLS }}$}

$\overline{\mathrm{ROA}}=$

$\begin{array}{lcc}\text { Gov } & -0.130 & (0.00) \\ \text { CEO Own } & 0.079 & (0.34) \\ \text { Leverage } & -0.054 & (0.00)\end{array}$

Sample Size

5,101

\section{Hausman (1978) Specification Test:}

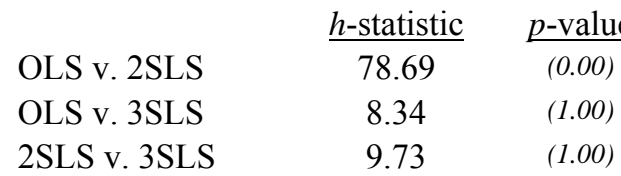

Stock and Yogo (2004) Weak Instruments Test:

\begin{tabular}{|c|c|c|}
\hline & $\begin{array}{l}\text { First-Stage } \\
\text { F-Statistic }\end{array}$ & $\begin{array}{c}\text { Critical } \\
\text { Value }\end{array}$ \\
\hline Gov & 160.33 & 9.53 \\
\hline CEO Own & 250.54 & 9.53 \\
\hline everage & 96.51 & 9.53 \\
\hline
\end{tabular}

Next 1 Year Performance
Next 2 Years Performance $\underline{\text { OLS }}$ $\mathrm{ROA}=$

$\begin{array}{lcc} & \text { Estimate } & \frac{\text { value }}{(0.00)} \\ \text { Gov } & -0.052 & \\ \text { CEO Own } & 0.045 & (0.02) \\ \text { Leverage } & -0.033 & (0.00)\end{array}$

\section{$\underline{\text { 2SLS }}$}

$\mathrm{ROA}=$

$(0.00)$

\section{$\underline{3 S L S}$}

$\mathrm{ROA}=$

$(0.00)$

$00)$
Sample Size

OLS v. 2 SLS
OLS v. 3 SLS
2SLS v. 3 SLS

Gov

CEO Own

Leverage

$\begin{array}{lcc}\text { Gov } & -0.121 & (0.00) \\ \text { CEO Own } & 0.164 & (0.54) \\ \text { Leverage } & -0.027 & (0.00) \\ & & \\ & & \\ \text { Gov } & -0.120 & (0.00) \\ \text { CEO Own } & 0.162 & (0.06) \\ \text { Leverage } & -0.027 & (0.00)\end{array}$

5,053

\begin{tabular}{|c|c|}
\hline$\underline{h \text {-statistic }}$ & $p$-value \\
\hline 68.54 & $(0.00)$ \\
\hline-3.18 & - \\
\hline 4.54 & $(1.00)$ \\
\hline
\end{tabular}

First-Stage $\frac{\text { F-Statistic }}{161.12}$

$$
257.71
$$$$
107.47
$$

\section{$\underline{\text { OLS }}$ \\ $\mathrm{ROA}=$}

\section{SLS}

$\mathrm{ROA}=$

\section{SLS}

$\mathrm{ROA}=$

(

Sample Size

OLS v. 2SLS

OLS v. 3SLS

2SLS v. 3SLS

First-Stage Critical

Gov $\frac{\text { F-Statistic }}{118.53} \quad \frac{\text { Value }}{9.53}$

CEO Own

197.54

93.35
3,814

\begin{tabular}{|c|c|}
\hline$\underline{h \text {-statistic }}$ & $p$-value \\
\hline 36.39 & $(0.13)$ \\
\hline-4.41 & - \\
\hline 2.11 & (1.00) \\
\hline
\end{tabular}

Estimate p-value

$-0.020 \quad(0.00)$

$0.009 \quad(0.49)$

$-0.040 \quad(0.00)$

$\begin{array}{lcc}\text { Gov } & -0.068 & (0.01) \\ \text { CEO Own } & 0.029 & (0.62) \\ \text { Leverage } & -0.037 & (0.00)\end{array}$

$\begin{array}{lcc}\text { Gov } & -0.068 & (0.01) \\ \text { CEO Own } & 0.027 & (0.64) \\ \text { Leverage } & -0.037 & (0.00)\end{array}$

(1.00) 
Table 4

Panel H: Only the coefficient estimate on the governance variable in (1a) is presented; $p$-values are in parentheses. The estimation method deemed most appropriate by the Hausman (1978) specification test is in bold.

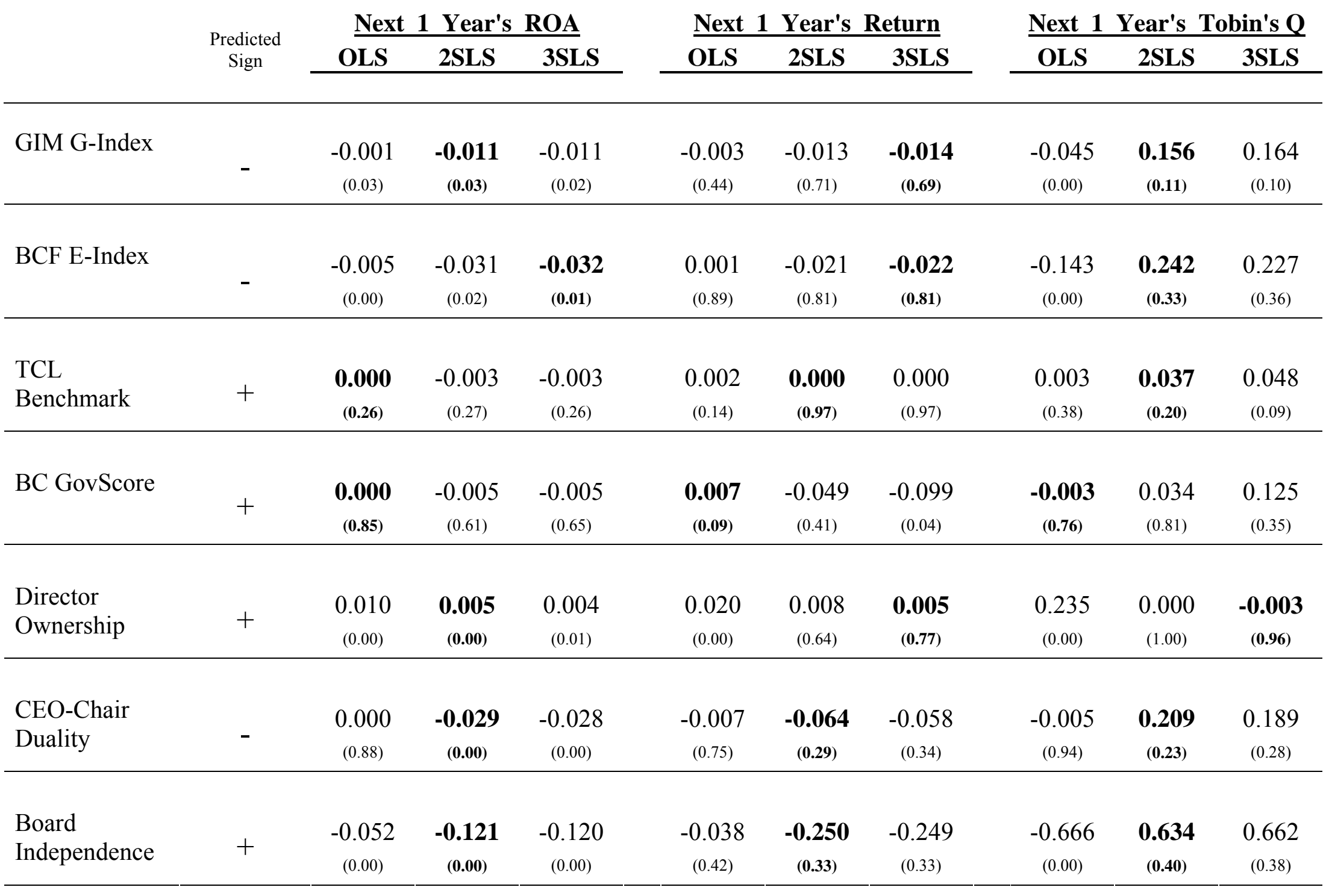


TABLE 5

Economic Significance of Governance Measures

In this table we report the elasticity of each significant governance measure, relative to operating performance ("ROA"). We include the following four governance measures for year $t$ : Gompers, Ishii and Metrick's (2003), median director stock ownership, and the Composite GOwnership Index which is constructed as follows: For each year, all firms are ranked from best to worst governed with respect to G-Index and median stock ownership, separately; we sum these two ranks to get the composite index for each year for each sample firm. Operating performance is measured by Return on Assets ("ROA") in three time periods: $t, t+1$, and $t+1$ to $t+2$. We calculate the elasticity using the coefficients reported in Table 4, and using the means and medians for each specific estimation sample. In Panel A, we report the elasticity using the mean values for governance and performance; in Panel B, we report the elasticity using the median values.

Panel A-Elasticity measured at means:

\begin{tabular}{lccc}
\hline & ROA $_{\mathbf{t}}$ & $\mathbf{R O A}_{\mathbf{t}+\mathbf{1}}$ & $\mathbf{R O A}_{\mathbf{t}+\mathbf{1} \text { to t+2 }}$ \\
\hline & & & \\
GIM G-Index & 0.854 & 0.763 & 0.287 \\
BCF E-Index & 0.583 & 0.529 & 0.266 \\
Director Ownership & 0.588 & 0.500 & 0.236 \\
Composite Index & 1.874 & 1.567 & 1.520 \\
& & & \\
\hline
\end{tabular}

$\underline{\text { Panel B - Elasticity measured at medians: }}$

\begin{tabular}{lccc}
\hline & $\mathbf{R O A}_{\mathbf{t}}$ & $\mathbf{R O A}_{\mathbf{t}+\mathbf{1}}$ & $\mathbf{R O A}_{\mathbf{t}+\mathbf{1} \text { to } \mathbf{+} \mathbf{2}}$ \\
\hline & & & \\
GIM G-Index & 0.864 & 0.779 & 0.296 \\
BCF E-Index & 0.557 & 0.510 & 0.264 \\
Director Ownership & 0.607 & 0.516 & 0.244 \\
Composite Index & 1.967 & 1.645 & 1.611 \\
& & & \\
\hline
\end{tabular}




\section{TABLE 6}

\section{k-Class Estimators}

In this table we report the results of estimating equation (1a) using different $k$-class estimators. We estimate equation (1) using contemporaneous operating performance ("ROA") and using the four governance variables. We estimate equation (1) using a different value of $k$ in each iteration, ranging from $k=0.0$ (OLS) to $k=1.0$ (2SLS), in increments of 0.1 . We also report the 3SLS results for comparison. Each column presents the results for a single governance measure and each value of $k$. Only the coefficients on the governance variable from equation (1a) are presented; $p$-values are in parentheses.

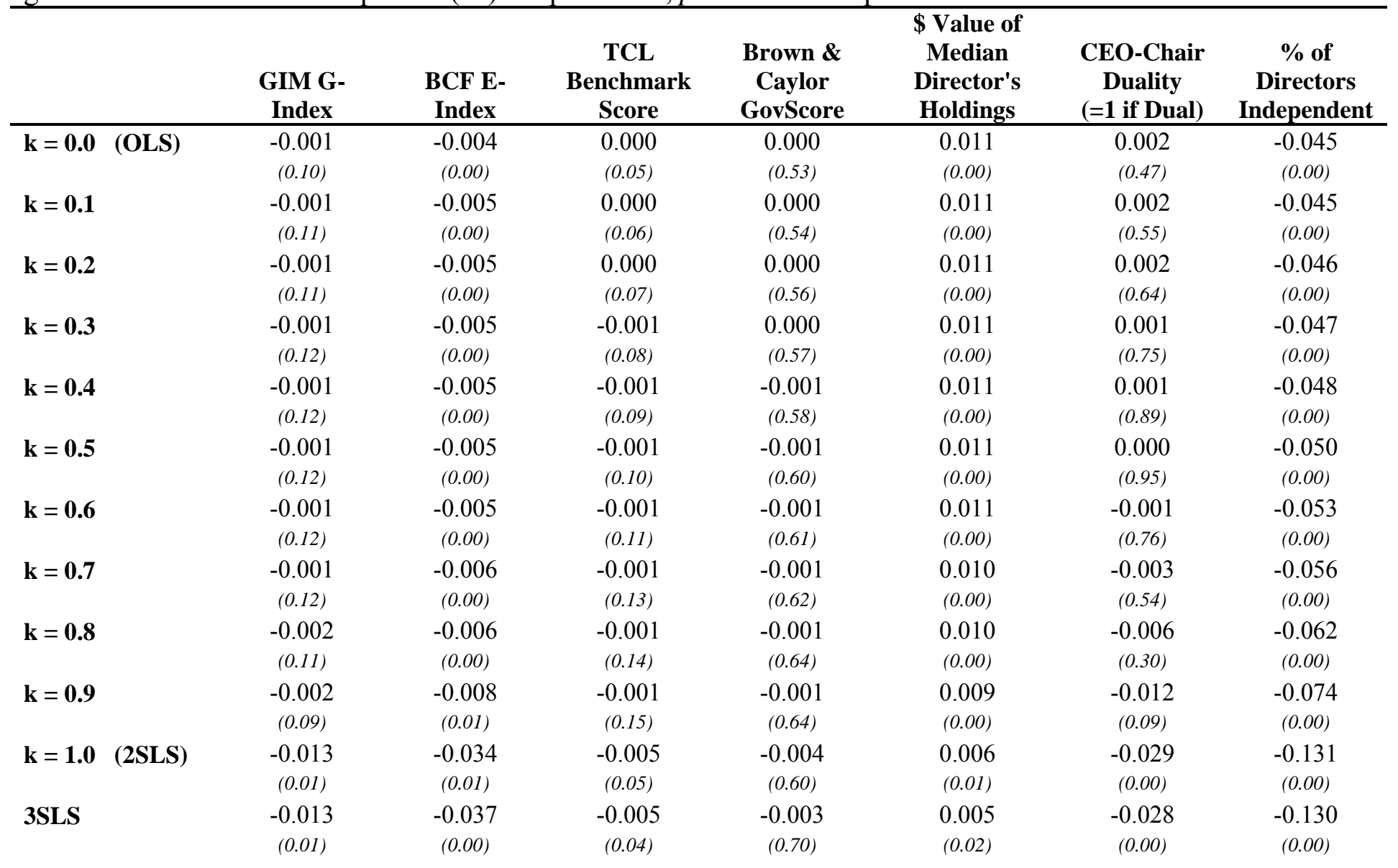


TABLE 7

Robustness to Serial Correlation of Errors

In this table we report the results from estimating equation (1a) using different approaches to address the possibility of serially correlated errors. We consider the full system of equations in (1), but used different estimation methods than in Table 4 as necessary for each approach. We consider five different approaches. In Panel A, we report results using OLS and clustered (Rogers) standard errors. In Panel B, we report results using 2SLS clustered standard errors, 2SLS using White standard errors, two fixed effects models, plus results from Table 4 for comparison. The performance measure is next year's Return on Assets $\left(\mathrm{ROA}_{t+1}\right)$. Only the coefficients on the governance variable from equation (1a) are presented; $p$-values are in parentheses.

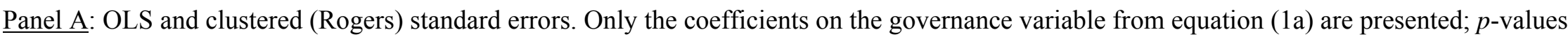
are in parentheses.

\begin{tabular}{|c|c|c|c|c|c|c|c|}
\hline & & & & vernance I & iable & & \\
\hline & $\begin{array}{l}\text { GIM G- } \\
\text { Index }\end{array}$ & $\begin{array}{l}\text { BCF E- } \\
\text { Index }\end{array}$ & $\begin{array}{c}\text { TCL } \\
\text { Benchmark } \\
\text { Score }\end{array}$ & $\begin{array}{c}\text { Brown \& } \\
\text { Caylor } \\
\text { GovScore } \\
\text { (OLS) }\end{array}$ & $\begin{array}{l}\$ \text { Value of } \\
\text { Median } \\
\text { Director's } \\
\text { Holdings }\end{array}$ & $\begin{array}{c}\text { CEO- } \\
\text { Chair } \\
\text { Duality } \\
\text { (=1 if } \\
\text { Dual) }\end{array}$ & $\begin{array}{c}\% \text { of Directors } \\
\text { Independent }\end{array}$ \\
\hline $\mathbf{R O A}_{\mathbf{t}}$ & $\begin{array}{c}-0.001 \\
(0.31)\end{array}$ & $\begin{array}{c}-0.004 \\
(0.00)\end{array}$ & $\begin{array}{l}0.000 \\
(0.09)\end{array}$ & $\begin{array}{l}0.000 \\
(0.57)\end{array}$ & $\begin{array}{l}0.011 \\
(0.00)\end{array}$ & $\begin{array}{l}0.002 \\
(0.61)\end{array}$ & $\begin{array}{c}-0.045 \\
(0.00)\end{array}$ \\
\hline \# of Observations & 4,600 & 4,600 & 2,199 & 811 & 5,101 & 5,101 & 5,101 \\
\hline $\mathbf{R O A}_{\mathbf{t}+1}$ & $\begin{array}{c}-0.001 \\
(0.19)\end{array}$ & $\begin{array}{c}-0.005 \\
(0.00)\end{array}$ & $\begin{array}{l}0.000 \\
(0.31)\end{array}$ & $\begin{array}{l}0.000 \\
(0.84)\end{array}$ & $\begin{array}{l}0.010 \\
(0.00)\end{array}$ & $\begin{array}{l}0.000 \\
(0.92)\end{array}$ & $\begin{array}{c}-0.052 \\
(0.00)\end{array}$ \\
\hline \# of Observations & 4,561 & 4,561 & 2,138 & 773 & 5,053 & 5,053 & 5,053 \\
\hline $\mathbf{R O A}_{\mathrm{t}+1 \text { to } \mathrm{t}+2}$ & $\begin{array}{c}-0.001 \\
(0.12)\end{array}$ & $\begin{array}{c}-0.002 \\
(0.00)\end{array}$ & $\begin{array}{l}0.000 \\
(0.60)\end{array}$ & $\begin{array}{l}- \\
-\end{array}$ & $\begin{array}{l}0.004 \\
(0.00)\end{array}$ & $\begin{array}{c}-0.004 \\
(0.12)\end{array}$ & $\begin{array}{c}-0.020 \\
(0.00)\end{array}$ \\
\hline \# of Observations & 3,416 & 3,416 & 977 & - & 3,814 & 3,814 & 3,814 \\
\hline
\end{tabular}


Panel B: Only the coefficients on the governance variable from equation (1a) are presented; $p$-values are in parentheses.

\begin{tabular}{|c|c|c|c|c|c|c|c|}
\hline & \multicolumn{7}{|c|}{ Governance Variable } \\
\hline & $\begin{array}{c}\text { GIM G- } \\
\text { Index }\end{array}$ & $\begin{array}{c}\text { BCF E- } \\
\text { Index }\end{array}$ & $\begin{array}{c}\text { TCL } \\
\text { Benchmark } \\
\text { Score }\end{array}$ & $\begin{array}{l}\text { Brown \& } \\
\text { Caylor } \\
\text { GovScore }\end{array}$ & $\begin{array}{c}\text { \$ Value of } \\
\text { Median } \\
\text { Director's } \\
\text { Holdings }\end{array}$ & $\begin{array}{c}\text { CEO- } \\
\text { Chair } \\
\text { Duality } \\
\text { (=1 if } \\
\text { Dual) }\end{array}$ & $\begin{array}{c}\% \text { of Directors } \\
\text { Independent }\end{array}$ \\
\hline OLS, Table 4 & $\begin{array}{c}-0.001 \\
(0.03)\end{array}$ & $\begin{array}{c}-0.005 \\
(0.00)\end{array}$ & $\begin{array}{l}0.000 \\
(0.26)\end{array}$ & $\begin{array}{l}0.000 \\
(0.85)\end{array}$ & $\begin{array}{l}0.010 \\
(0.00)\end{array}$ & $\begin{array}{l}0.000 \\
(0.88)\end{array}$ & $\begin{array}{c}-0.052 \\
(0.00)\end{array}$ \\
\hline OLS, Clustered SE & $\begin{array}{c}-0.001 \\
(0.19)\end{array}$ & $\begin{array}{c}-0.005 \\
(0.00)\end{array}$ & $\begin{array}{l}0.000 \\
(0.31)\end{array}$ & $\begin{array}{l}0.000 \\
(0.84)\end{array}$ & $\begin{array}{l}0.010 \\
(0.00)\end{array}$ & $\begin{array}{l}0.000 \\
(0.92)\end{array}$ & $\begin{array}{c}-0.052 \\
(0.00)\end{array}$ \\
\hline 2SLS, Table 4 & $\begin{array}{c}-0.011 \\
(0.03)\end{array}$ & $\begin{array}{c}-0.031 \\
(0.02)\end{array}$ & $\begin{array}{c}-0.003 \\
(0.27)\end{array}$ & $\begin{array}{c}-0.005 \\
(0.61)\end{array}$ & $\begin{array}{l}0.005 \\
(0.04)\end{array}$ & $\begin{array}{c}-0.029 \\
(0.00)\end{array}$ & $\begin{array}{c}-0.121 \\
(0.00)\end{array}$ \\
\hline 2SLS, Clustered SE & $\begin{array}{c}-0.011 \\
(0.07)\end{array}$ & $\begin{array}{c}-0.031 \\
(0.09)\end{array}$ & $\begin{array}{c}-0.003 \\
(0.23)\end{array}$ & $\begin{array}{c}-0.005 \\
(0.84)\end{array}$ & $\begin{array}{l}0.005 \\
(0.07)\end{array}$ & $\begin{array}{c}-0.029 \\
(0.01)\end{array}$ & $\begin{array}{c}-0.121 \\
(0.01)\end{array}$ \\
\hline 2SLS, White SE & $\begin{array}{c}-0.011 \\
(0.05)\end{array}$ & $\begin{array}{c}-0.031 \\
(0.10)\end{array}$ & $\begin{array}{c}-0.003 \\
(0.09)\end{array}$ & $\begin{array}{l}-0.005 \\
(0.84)\end{array}$ & $\begin{array}{l}0.005 \\
(0.06)\end{array}$ & $\begin{array}{c}-0.029 \\
(0.02)\end{array}$ & $\begin{array}{c}-0.121 \\
(0.04)\end{array}$ \\
\hline $\begin{array}{l}\text { Fixed Effects } \\
\text { Firm and Year FE }\end{array}$ & $\begin{array}{c}-0.005 \\
(0.00)\end{array}$ & $\begin{array}{c}-0.004 \\
(0.02)\end{array}$ & $\begin{array}{l}0.000 \\
(0.25)\end{array}$ & $\begin{array}{l}- \\
-\end{array}$ & $\begin{array}{l}0.003 \\
(0.00)\end{array}$ & $\begin{array}{l}0.002 \\
(0.42)\end{array}$ & $\begin{array}{r}-0.017 \\
(0.02)\end{array}$ \\
\hline $\begin{array}{l}\text { FE, Clustered SE } \\
\text { Firm and Year FE }\end{array}$ & $\begin{array}{c}-0.005 \\
(0.01)\end{array}$ & $\begin{array}{c}-0.004 \\
(0.08)\end{array}$ & $\begin{array}{l}0.000 \\
(0.30)\end{array}$ & - & $\begin{array}{l}0.003 \\
(0.03)\end{array}$ & $\begin{array}{l}0.002 \\
(0.50)\end{array}$ & $\begin{array}{l}-0.017 \\
(0.06)\end{array}$ \\
\hline
\end{tabular}


TABLE 8

Reasons for CEO Turnover

This table presents the classifications for reasons why CEO turnover occurred in a specific year. Lexis-Nexis archives were reviewed to determine the stated reason for why a CEO left the firm. CEO turnover data was obtained from Compustat's Execucomp database. CEO Turnover is classified as "Non-disciplinary" if the CEO died, if the CEO was older than 63, if the change was the result of an announced transition plan, or if the CEO stayed on as chairman of the board for a nontrivial length of time. CEO Turnover is classified as "Disciplinary" if the CEO resigned to pursue other interests, if the CEO was fired, or if no specific reason is given.

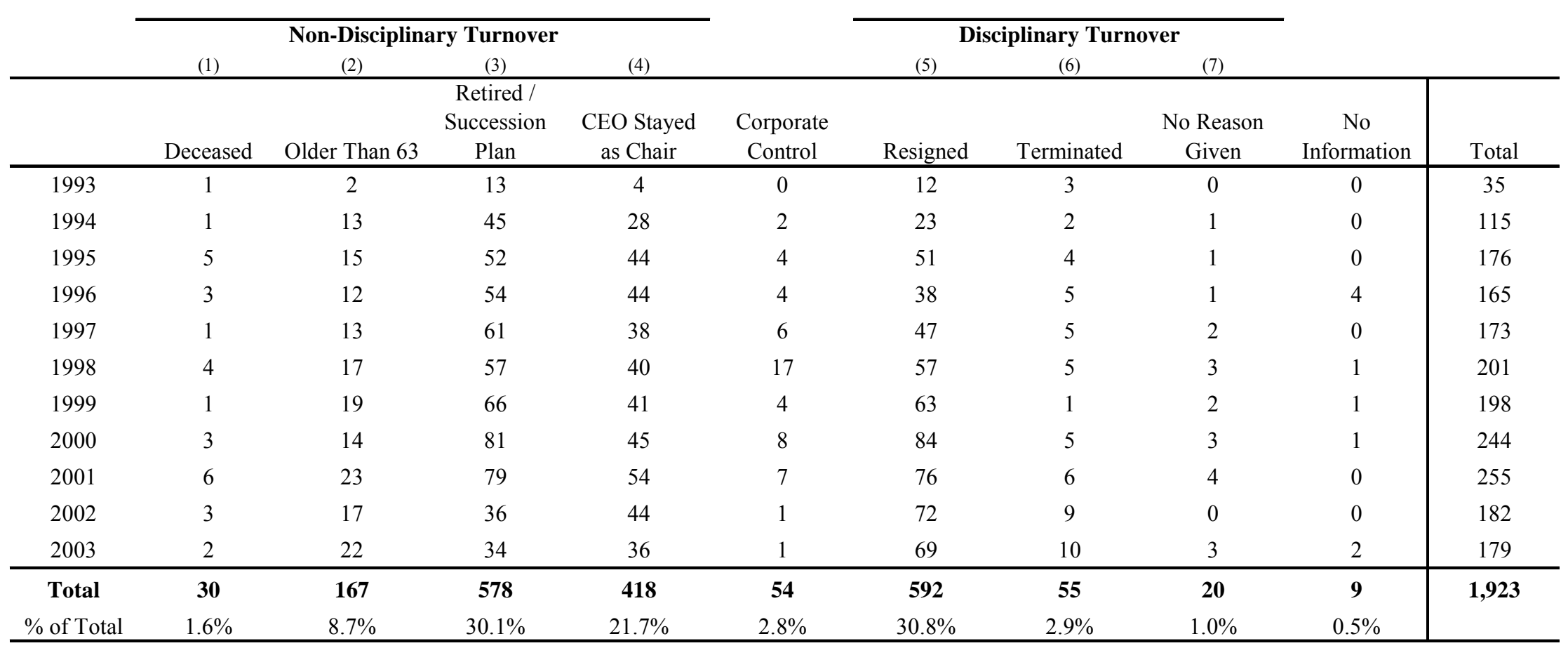


TABLE 9

Multinomial Logit Models for CEO Turnover

This table presents the results from multinomial logistic regressions estimating the probability of CEO Turnover. The dependent variables are type of CEO turnover: $1=$ Disciplinary turnover, $2=$ Non-disciplinary turnover, $0=$ no turnover. No turnover is the baseline category. Baseline results are presented in the first column; all other columns present results including Governance and (Performance $x$ Governance) variables. The other control variables are described in Table 1. Year dummy variables are included but are not shown. Panel A presents the results for disciplinary turnover for all available years; Panel B presents the results for nondisciplinary turnover for all available years.

\section{Panel A: Disciplinary Turnover}

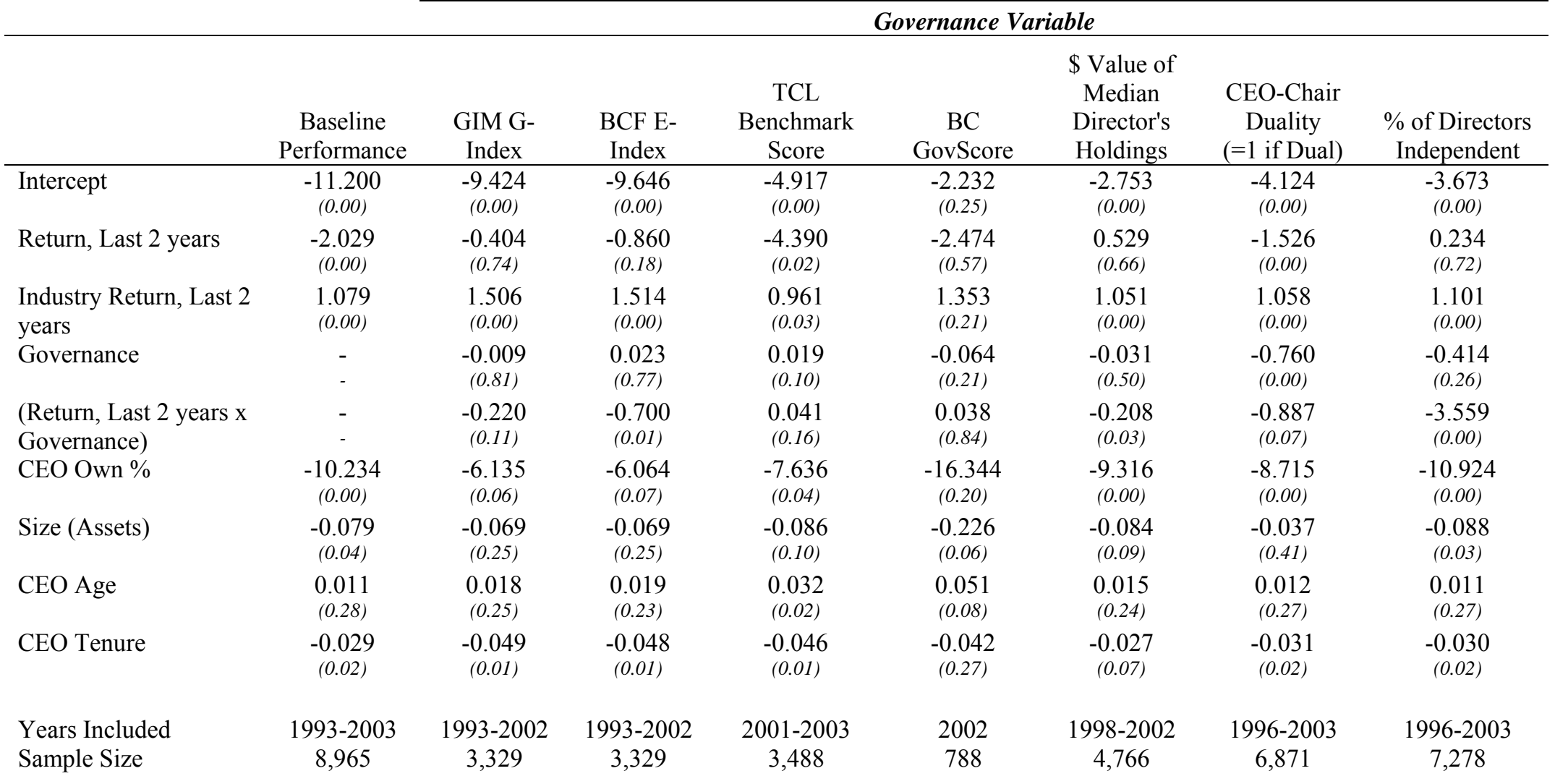




\begin{tabular}{|c|c|c|c|c|c|c|c|c|}
\hline \multirow[t]{2}{*}{ 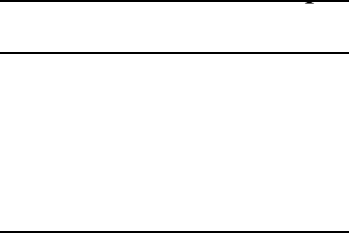 } & & \multicolumn{7}{|c|}{ Governance Variable } \\
\hline & $\begin{array}{c}\text { Baseline } \\
\text { Performance }\end{array}$ & $\begin{array}{l}\text { GIM G- } \\
\text { Index }\end{array}$ & $\begin{array}{l}\text { BCF E- } \\
\text { Index }\end{array}$ & $\begin{array}{c}\text { TCL } \\
\text { Benchmark } \\
\text { Score }\end{array}$ & $\begin{array}{c}\text { BC } \\
\text { GovScore }\end{array}$ & $\begin{array}{l}\text { \$ Value of } \\
\text { Median } \\
\text { Director's } \\
\text { Holdings }\end{array}$ & $\begin{array}{c}\text { CEO-Chair } \\
\text { Duality } \\
(=1 \text { if Dual })\end{array}$ & $\begin{array}{l}\% \text { of Directors } \\
\text { Independent }\end{array}$ \\
\hline Intercept & $\begin{array}{c}-13.696 \\
(0.00)\end{array}$ & $\begin{array}{c}-11.506 \\
(0.00)\end{array}$ & $\begin{array}{c}-11.589 \\
(0.00)\end{array}$ & $\begin{array}{c}-10.011 \\
(0.00)\end{array}$ & $\begin{array}{c}-7.577 \\
(0.00)\end{array}$ & $\begin{array}{c}-9.809 \\
(0.00)\end{array}$ & $\begin{array}{c}-12.053 \\
(0.00)\end{array}$ & $\begin{array}{c}-11.665 \\
(0.00)\end{array}$ \\
\hline Return, Last 2 years & $\begin{array}{c}-0.333 \\
(0.05)\end{array}$ & $\begin{array}{r}0.327 \\
(0.70)\end{array}$ & $\begin{array}{r}0.113 \\
(0.80)\end{array}$ & $\begin{array}{c}-0.048 \\
(0.97)\end{array}$ & $\begin{array}{c}-1.744 \\
(0.66)\end{array}$ & $\begin{array}{c}-1.507 \\
(0.12)\end{array}$ & $\begin{array}{c}-0.268 \\
(0.33)\end{array}$ & $\begin{array}{c}0.229 \\
(0.63)\end{array}$ \\
\hline $\begin{array}{l}\text { Industry Return, Last } 2 \\
\text { years }\end{array}$ & $\begin{array}{l}0.187 \\
(0.43)\end{array}$ & $\begin{array}{r}0.562 \\
(0.12)\end{array}$ & $\begin{array}{c}0.564 \\
(0.12)\end{array}$ & $\begin{array}{c}-0.134 \\
(0.71)\end{array}$ & $\begin{array}{c}0.353 \\
(0.70)\end{array}$ & $\begin{array}{c}0.375 \\
(0.18)\end{array}$ & $\begin{array}{l}0.150 \\
(0.57)\end{array}$ & $\begin{array}{l}0.245 \\
(0.32)\end{array}$ \\
\hline Governance & $\begin{array}{l}- \\
-\end{array}$ & $\begin{array}{c}0.014 \\
(0.65)\end{array}$ & $\begin{array}{c}0.070 \\
(0.25)\end{array}$ & $\begin{array}{r}0.005 \\
(0.60)\end{array}$ & $\begin{array}{c}-0.067 \\
(0.13)\end{array}$ & $\begin{array}{c}-0.016 \\
(0.67)\end{array}$ & $\begin{array}{c}-1.071 \\
(0.00)\end{array}$ & $\begin{array}{c}-0.071 \\
(0.81)\end{array}$ \\
\hline $\begin{array}{l}\text { (Return, Last } 2 \text { years x } \\
\text { Governance) }\end{array}$ & $\begin{array}{l}- \\
-\end{array}$ & $\begin{array}{c}-0.064 \\
(0.50)\end{array}$ & $\begin{array}{c}-0.164 \\
(0.38)\end{array}$ & $\begin{array}{c}-0.004 \\
(0.82)\end{array}$ & $\begin{array}{l}0.045 \\
(0.79)\end{array}$ & $\begin{array}{r}0.081 \\
(0.22)\end{array}$ & $\begin{array}{c}0.040 \\
(0.90)\end{array}$ & $\begin{array}{c}-0.824 \\
(0.27)\end{array}$ \\
\hline CEO Own \% & $\begin{array}{c}-19.271 \\
(0.00)\end{array}$ & $\begin{array}{c}-17.296 \\
(0.00)\end{array}$ & $\begin{array}{c}-17.090 \\
(0.00)\end{array}$ & $\begin{array}{c}-15.420 \\
(0.00)\end{array}$ & $\begin{array}{c}-8.386 \\
(0.07)\end{array}$ & $\begin{array}{c}-15.350 \\
(0.00)\end{array}$ & $\begin{array}{c}-18.282 \\
(0.00)\end{array}$ & $\begin{array}{c}-19.644 \\
(0.00)\end{array}$ \\
\hline Size (Assets) & $\begin{array}{c}-0.015 \\
(0.60)\end{array}$ & $\begin{array}{c}-0.065 \\
(0.15)\end{array}$ & $\begin{array}{c}-0.062 \\
(0.17)\end{array}$ & $\begin{array}{c}-0.012 \\
(0.77)\end{array}$ & $\begin{array}{c}-0.073 \\
(0.43)\end{array}$ & $\begin{array}{r}0.001 \\
(0.97)\end{array}$ & $\begin{array}{c}0.059 \\
(0.06)\end{array}$ & $\begin{array}{c}-0.020 \\
(0.51)\end{array}$ \\
\hline CEO Age & $\begin{array}{l}0.133 \\
(0.00)\end{array}$ & $\begin{array}{c}0.133 \\
(0.00)\end{array}$ & $\begin{array}{l}0.133 \\
(0.00)\end{array}$ & $\begin{array}{c}0.130 \\
(0.00)\end{array}$ & $\begin{array}{l}0.123 \\
(0.00)\end{array}$ & $\begin{array}{c}0.129 \\
(0.00)\end{array}$ & $\begin{array}{c}0.136 \\
(0.00)\end{array}$ & $\begin{array}{c}0.136 \\
(0.00)\end{array}$ \\
\hline CEO Tenure & $\begin{array}{c}0.018 \\
(0.00)\end{array}$ & $\begin{array}{c}0.016 \\
(0.10)\end{array}$ & $\begin{array}{c}0.017 \\
(0.09)\end{array}$ & $\begin{array}{c}0.028 \\
(0.00)\end{array}$ & $\begin{array}{c}0.022 \\
(0.26)\end{array}$ & $\begin{array}{c}0.010 \\
(0.19)\end{array}$ & $\begin{array}{l}0.011 \\
(0.14)\end{array}$ & $\begin{array}{c}0.013 \\
(0.06)\end{array}$ \\
\hline Years Included & $1993-2003$ & 1993-2002 & 1993-2002 & 2001-2003 & 2002 & $1998-2002$ & $1996-2003$ & $1996-2003$ \\
\hline Sample Size & 8,965 & 3,329 & 3,329 & 3,488 & 788 & 4,766 & 6,871 & 7,278 \\
\hline
\end{tabular}

